\title{
Simulation of C1s Spectra of C- and O-Containing Polymers in XPS by $A b$ Initio MO Calculations Using Model Oligomers
}

\author{
Kazunaka Endo, Shigehiro MAEDA, and Masayuki AIDA \\ Tsukuba Research Laboratory, Mitsubishi Paper Mills, Ltd., \\ 46 Wadai, Tsukuba, Ibaraki 300-42, Japan
}

(Received August 29, 1996)

\begin{abstract}
C} 1 \mathrm{~s}$ spectra of molecules $\left[\mathrm{CH}_{2}=\mathrm{CH}(\mathrm{COOH}), \mathrm{CH}_{2}=\mathrm{CH}-\mathrm{COOCH}{ }_{3}, \mathrm{CH}_{2}=\mathrm{C}\left(\mathrm{CH}_{3}\right) \mathrm{COOCH}_{3}, \mathrm{CH}_{3}-\mathrm{CH}_{-}\right.$ $\left.\left(\mathrm{CH}_{3}\right) \mathrm{COOCH}_{3}\right]$ in gas and fifteen polymers $\left[\left(\mathrm{CH}_{2}-\mathrm{CHR}\right)_{n}\left(\mathrm{R}=\mathrm{H}, \mathrm{CH}_{3}, \mathrm{OH}, \mathrm{OCH}_{3}, \mathrm{COCH}_{3}, \mathrm{COOH}_{2} \mathrm{OCOCH}_{3}, \mathrm{COOCH}_{3}\right)\right.$, $\left((\mathrm{CH})_{k}-\mathrm{O}\right)_{n}(k=1-4),(\mathrm{CHR}-\mathrm{CO}-\mathrm{O})_{n}\left(\mathrm{R}=\mathrm{H}, \mathrm{CH}_{3}\right)$, and $\left.\left(\mathrm{CH}_{2}-\mathrm{C}\left(\mathrm{CH}_{3}\right) \mathrm{COOCH}_{3}\right)_{n}\right]$ in X-ray photoelectron spectroscopy (XPS) were simulated from Koopmans' theorem by ab initio MO calculations of HONDO7 program using the model oligomers. The calculated Cls spectra were obtained using Gaussian lineshape functions of each fixed linewidth of 0.54 and $1.3 \mathrm{eV}$ for the gas molecules and the oligomers, respectively. The theoretical spectra showed fairly good accordance with the experimental spectra, although the shifted values were used as 14.4 and $21.0 \mathrm{eV}$ for core $\mathrm{C} 1 \mathrm{~s}$ energy levels of the gas molecules and the model oligomers, respectively. The difference between the shifted values ( 21.0 and $14.4 \mathrm{eV})$ approaches to the WD (5.2-6.4 eV) of ten polymers as obtained by deMon density-functional calculations using model molecules with scaled-pVTZ basis set. This is due to the relation of solid effects between the experimental core-electron binding energies of polymers and theoretical MO eigenvalues of the oligomer models, as stated in the previous work.
\end{abstract}

KEY WORDS X-Ray Photoelectron Spectroscopy / C1s Spectra / Ab Initio MO / Spectral Simulation / Koopmans' Theorem / O-Containing Polymer / Work Function /

We have currently reported on the simulation of Xray photoelectron spectra of polymers by $\mathrm{MO}$ calculations using the model molecules. ${ }^{1-10}$ The theorem of the MO calculations can be classified into three typical cases: (a) the Koopmans' theorem, (b) delta-SCF, and (c) Slaters' concept ${ }^{11}$ of the transition-state. In the case (a), we offered a good analysis ${ }^{2-4}$ of C1s spectra with Koopmans' values for four polymers $\left[\left(\mathrm{CH}_{2}-\mathrm{CHR}\right)_{n}\right.$ $\left(\mathrm{R}=\mathrm{OH}, \mathrm{COOH}, \mathrm{OCOCH}_{3}\right)$ and $\left(\mathrm{CH}_{2}-\mathrm{C}\left(\mathrm{CH}_{3}\right) \mathrm{COO}-\right.$ $\left.\mathrm{CH}_{3}\right)_{n}$, although the shifted value was used as $21.0 \mathrm{eV}$ for core $\mathrm{C} 1 \mathrm{~s}$ energy levels of the model oligomers. The reason relies on it that the differences between core energy levels as obtained using calculations of the neutral parent molecules approximate the ones as observed for the ionized molecules in XPS, although the nuclear positive charges strongly attract the core electrons in the deep potential of the ionized state. However, in the case of valence electron spectra, the energy scale of the simulated spectra ${ }^{12-14}$ using the Koopmans' theorem had to be contracted and shifted for a good fit with the observed spectra. This means that the energy levels in valence electron region of a ionized molecule are narrowed more than the Koopmans' values in the range of the neutral parent molecule, since there are valence electrons in the shallow potential.

The method of delta-SCF (case (b)) gave quite reliable values ${ }^{15,16}$ of the core-electron binding energies (CEBEs), but suffers from occasional failures. In recent papers, ${ }^{5-10}$ we have performed the theoretical better assignment of valence-band spectra for 60 polymers due to Slater's idea of the transition-state (case (c)) by semiempirical HAM $/ 3^{17-20}$ and $a b$ initio deMon density functional ${ }^{21}$ calculations using the model oligomers. The simulation spectra from the MO calculations in that the results can be directly compared with experiment to predict vertical ionization potentials (VIPs) were in good accordance with observed spectra.

For the CEBEs, in $a b$ initio studies of the density functional theory (DFT) using the deMon DFT program, ${ }^{21}$ Chong ${ }^{2-26}$ offered the methods of calculating accurate CEBEs of small molecules. We have also reported on the applications ${ }^{9,10}$ of the DFT to calculate the CEBEs of the polymers. The difference between the calculated and the observed CEBEs reflected the trend in WD (sum of work function and other energy effects) of the polymers.

In the present paper, we describe a comprehensive study on the simulation of $\mathrm{Cls}$ spectra of $\mathrm{C}$ - and $\mathrm{O}$ containing polymers in XPS due to Koopmans' theorem by $a b$ initio MO calculations using HONDO7 program. ${ }^{27}$ Furthermore, the CEBEs of $\mathrm{C} 1 \mathrm{~s}$ for the model molecules of polymers $\left[\left(\mathrm{CH}_{2}-\mathrm{CHR}\right)_{n}\left(\mathrm{R}=\mathrm{H}, \mathrm{CH}_{3}, \mathrm{OH}\right.\right.$, $\left.\mathrm{OCH}_{3}, \mathrm{COCH}_{3}, \mathrm{COOH}, \mathrm{COOCH}_{3}\right),\left(\mathrm{CH}_{2}-\mathrm{O}\right)_{n},\left(\mathrm{CH}_{2}-\right.$ $\mathrm{CO}-\mathrm{O})_{n}$, and $\left.\left(\mathrm{CH}_{2}-\mathrm{C}\left(\mathrm{CH}_{3}\right) \mathrm{COOCH}_{3}\right)_{n}\right]$ are calculated by deMon DFT program ${ }^{21}$ with scaled polarized valence triple-zeta (pVTZ) basis set. The results showed much better correspondence with experiment than were those predicted by Koopmans' theorem.

\section{THEORETICAL AND DETAIL OF CALCULATION}

\section{Simulation of Cls Spectra Due to Koopmans' Theorem}

The model molecules $\left[\mathrm{CH}_{2}=\mathrm{CH}(\mathrm{COOH}), \mathrm{CH}_{2}=\right.$ $\mathrm{CH}-\mathrm{COOCH}_{3}, \mathrm{CH}_{2}=\mathrm{C}\left(\mathrm{CH}_{3}\right) \mathrm{COOCH}_{3}, \mathrm{CH}_{3}-\mathrm{CH}-$ $\left.\left(\mathrm{CH}_{3}\right) \mathrm{COOCH}_{3}\right]$ in gas, and $\left[\mathrm{H}-\left(\mathrm{CH}_{2}-\mathrm{CHR}\right)_{m}-\mathrm{H}(\mathrm{R}\right.$; $m=\mathrm{H} ; 3, \mathrm{CH}_{3} ; 3, \mathrm{OH} ; 3, \mathrm{OCH}_{3} ; 2, \mathrm{COCH}_{3} ; 2, \mathrm{COOH}$; $\left.3, \mathrm{OCOCH}_{3} ; 3, \mathrm{COOCH}_{3} ; 2\right), \mathrm{H}-\left((\mathrm{CH})_{k}-\mathrm{O}\right)_{m}-\mathrm{H}(k$; $m=1 ; 3,2 ; 3,3 ; 2,4 ; 2), \mathrm{H}-(\mathrm{CHR}-\mathrm{CO}-\mathrm{O})_{m}-\mathrm{H}(\mathrm{R} ; m=\mathrm{H}$; $\left.2, \mathrm{CH}_{3} ; 2\right)$, and $\left.\mathrm{H}-\left(\mathrm{CH}_{2}-\mathrm{C}\left(\mathrm{CH}_{3}\right) \mathrm{COOCH}_{3}\right)_{2}-\mathrm{H}\right]$ of polymers were calculated by $a b$ initio RHF-SCF MO calculations using the HONDO7 program. For $\mathrm{C}$ and $\mathrm{O}$ atoms, we used the $(4 \mathrm{~s} 2 \mathrm{p})$ basis sets and for $\mathrm{H}$ atoms, we used $2 \mathrm{~s}$ basis set reported by Huzinaga et al. ${ }^{28}$ and Dunning et al. ${ }^{29}$ For the geometry of the model molecules, we used the optimized structures from the semi- 
empirical AM1 (version 6.0) ${ }^{30}$ MO calculations.

The electronic states of the polymers by the MO calculations using the dimer or the trimer model molecules will enhance the effects of the edges of the main chain. Then, we omitted the contribution of both edge segments of the main chain, in order to simulate the Cls core-electron spectra.

For the comparison between calculations for single molecules of the dimer or trimer models and experiments on a solid polymer, we must shift each computed CEBEs, $E_{\mathrm{k}}^{\prime}$ by a quantity $\left(E_{\mathrm{DKT}}+\mathrm{WD}\right)$ as $E_{\mathrm{k}}\left(E_{\mathrm{F}}\right)=E_{\mathrm{k}}^{\prime}-\left(E_{\mathrm{DKT}}+\right.$ WD), to convert to ionization energy $E_{\mathrm{k}}\left(E_{\mathrm{F}}\right)$ relative to the Fermi level. These quantities were stated in the previous work. ${ }^{4}$ In this work, we chose the fixed approximate values of the quantity $E_{\mathrm{DKT}}$ as $14.4 \mathrm{eV}$ for C1s spectra of gas molecules and of the $\operatorname{sum}\left(E_{\mathrm{DKT}}+\mathrm{WD}\right)$ as $21.0 \mathrm{eV}$ for $\mathrm{C} 1 \mathrm{~s}$ spectra of polymers, respectively, to provide the good agreement on the location of the main features of the simulated spectrum.

In order to simulate the core-electron spectra of $\mathrm{C} 1 \mathrm{~s}$ of the gas molecules and polymers, we used the Gaussian lineshape function:

$$
f(x)=A(k) \exp \left\{-B(k)\left(x-E_{k}\right)^{2}\right\}
$$

where the intensity, $A(k)$, is estimated as an arbitrary unit. For the linewidth, $W H(k)=2(\ln 2 / B(k))^{1 / 2}$, we found the fixed approximate values as 0.54 and $1.3 \mathrm{eV}$ for $\mathrm{Cls}$ of gas molecules and polymer models, respectively, by trial and error.

\section{CEBEs of C1s Due to Slater's Concept of the Transition-}

\section{State Using DFT Calculations}

We can consider an electronic process of ionization or excitation for single molecules using Slater's transitionstate (TS) method at fixed molecular geometry. We define

$$
\begin{aligned}
E(x) & =\sum x^{k} E_{k} \\
& =E_{0}+x E_{1}+x^{2} E_{2}+x^{3} E_{3}+x^{4} E_{4}+\cdots
\end{aligned}
$$

where $E(0)$ and $E(1)$ correspond to the initial and final states respectively and $x$ is assumed to be a continuous variable. From eq 2 , the endothermicity we seek is given by

$$
\Delta E=E(1)-E(0)=E_{1}+E_{2}+E_{3}+E_{4}+\cdots
$$

If we define the first derivative $(F(x)=\mathrm{d} E(x) / \mathrm{d} x)$, in the generalized transition-state (GTS) method, Williams et al. ${ }^{31}$ propposed the use of

$$
F(2 / 3)=E_{1}+4 E_{2} / 3+4 E_{3} / 3+32 E_{4} / 27+\cdots
$$

Therefore, $\Delta E$ can be approximated by

$$
[F(0)+3 F(2 / 3)] / 4=E_{1}+E_{2}+E_{3}+8 E_{4} / 9+\cdots
$$

with an error of only

$$
\mathrm{d}_{\mathrm{GTS}}=-E_{4} / 9+\cdots
$$

The GTS model can be applied in two ways. In what is labeled 'restricted' GTS method, we remove the same set of fractional electrons from molecular orbitals for both alpha and beta electrons, rather than MO for alpha electron(s) only in the 'unrestricted' GTS model. For uGTS models, the corresponding number is $2 / 3$.

The model molecules $\left[\mathrm{H}-\left(\mathrm{CH}_{2}-\mathrm{CHR}\right)_{2}-\mathrm{H} \quad(\mathrm{R}=\mathrm{H}\right.$,
$\left.\mathrm{CH}_{3}, \mathrm{COCH}_{3}\right), \mathrm{H}-\left(\mathrm{CH}_{2}-\mathrm{CHR}-\mathrm{CH}_{2}\right)-\mathrm{H}(\mathrm{R}=\mathrm{OH}$, $\left.\mathrm{OCH}_{3}\right), \mathrm{H}-\left(\mathrm{CH}_{2}-\mathrm{CHR}\right)-\mathrm{H} \quad\left(\mathrm{R}=\mathrm{COOH}, \mathrm{COOCH}_{3}\right)$, $\mathrm{H}-\left(\mathrm{CH}_{2}-\mathrm{O}\right)_{2}-\mathrm{H}, \mathrm{H}-\left(\mathrm{CH}_{2}-(\mathrm{CO})-\mathrm{O}-\mathrm{CH}_{2}\right)-\mathrm{H}$, and $\mathrm{H}-$ $\left.\left(\mathrm{CH}_{2}-\mathrm{C}\left(\mathrm{CH}_{3}\right) \mathrm{COOCH}_{2}\right)-\mathrm{H}\right]$ were calculated by the density functional theory using deMon program. ${ }^{21}$ For the geometry of the molecules, we used the optimized cartesian coordinates from the semiempirical AM1 (version 6.0) program. The deMon calculations were performed with the exchange-correlation potential labeled as B88/P86, made from Beck's 1988 exchange functional $^{32}$ and Perdew's 1986 correlation functional. ${ }^{33}$ In the program, we used a nonrandom grid and a scaled polarized valence triple-zeta (scaled-pVTZ) ${ }^{25}$ basis set for $\mathrm{C}, \mathrm{O}$, and $\mathrm{H}$ with auxiliary fitting functions labeled $(4,4 ; 4,4)$ for $\mathrm{C}$ and $\mathrm{O}(3,1 ; 3,1)$ for $\mathrm{H}$.

In the calculation of CEBEs, we used the uGTS models for the model molecules of ten polymers. We added the relativistic correction $\left(C_{\mathrm{rel}}\right)^{24,25}$ for $C$ using $C_{\mathrm{rel}}=K I_{\mathrm{nr}} N$ where $K=2.198 \times 10^{-7}, N=2.178$ and $I_{\mathrm{nr}}$ is the nonrelativistic CEBE.

For four gas molecules and fifteen polymers, we cited the Cls spectra in XPS by Naves de Brito et al. ${ }^{15}$ and Beamson and Briggs, ${ }^{34}$ respectively.

\section{RESULTS AND DISCUSSION}

Simulation of C1s Photoelectron Spectra of Gas Molecules

As stated in Introduction, we considered that the core-electron spectra can be simulated with the Koopmans' theorem of neutral parent molecules, since the differences between energy levels as obtained using the Koopmans' theorem approximate the ones in an ionized state of core-electron after the X-ray irradiation. We simulated $\mathrm{C} 1 \mathrm{~s}$ spectra of organic gas molecules $\left[\mathrm{CH}_{2}=\mathrm{CH}(\mathrm{COOH}), \mathrm{CH}_{2}=\mathrm{CH}-\mathrm{COOCH}_{3}, \mathrm{CH}_{2}=\right.$ $\left.\mathrm{C}\left(\mathrm{CH}_{3}\right) \mathrm{COOCH}_{3}, \mathrm{CH}_{3}-\mathrm{CH}\left(\mathrm{CH}_{3}\right) \mathrm{COOCH}_{3}\right]$ as models of the $\mathrm{C}$ - and $\mathrm{O}$-containing polymers as already observed by Neves de Brito and coworkers. ${ }^{15,16}$

For this simulation, we used fixed energy shifts and fixed linewidths for each MO level of the calculated $\mathrm{Cls}$, since we considered the these molecules which consist of three common atoms $\mathrm{C}, \mathrm{H}$, and $\mathrm{O}$. By trial and error, we found the energy shifted value as $14.4 \mathrm{eV}$ for $\mathrm{Cls}$ between the Koopmans' values and the observed results of the four molecules. The linewidth of each MO levels for $\mathrm{C} 1 \mathrm{~s}$ was evaluated as $0.54 \mathrm{eV}$, as shown in Table I. Figure $1 \mathrm{a}-\mathrm{d}$ indicates that we can obtain good assignments with the Koopmans' theorem due to the normal MO calculations of the neutral parent molecules using the ab initio MO program.

\section{Simulation of C1s Spectra of Fifteen Polymers}

The simulated $\mathrm{Cls}$ spectra as obtained by MO calculations using model oligomers, correspond to the experimental core electron spectra of the polymers (as shown in Figures $2 \mathrm{a}-5 \mathrm{~d}$ ), although there was a large difference $(21.0 \mathrm{eV})$ in energy levels due to the Koopmans' value and WD (work function and other energy effects). In the simulation, we also used a fixed energy shift and a fixed linewidth for MO levels of C1s of these C- and O-containing polymers.

In the case of the spectral analysis, we omitted the contribution of both edge segments of main chain. The 
Table I. C1s binding energies (in eV) of acrylic acid (ACRA), methyl acrylate (MA), methyl methacrylate (MMA), and methyl isobutyrate (MIB) in gas by HONDO7 program

\begin{tabular}{|c|c|c|c|c|c|}
\hline Molecule & Observed $^{\mathrm{b}}$ & $\begin{array}{c}\text { Koopmans' } \\
\text { theorem }\end{array}$ & $\begin{array}{l}\text { Relative } \\
\text { intensity }\end{array}$ & $\begin{array}{l}\text { Shifted } \\
\text { value }\end{array}$ & $\begin{array}{l}\text { Linewidth } \\
\text { (halfwidth) }\end{array}$ \\
\hline \multicolumn{6}{|l|}{ MIB } \\
\hline \multicolumn{6}{|l|}{$\mathrm{CH}_{3}-\mathrm{CH}\left(\mathrm{CH}_{3}\right) \mathrm{COOCH}_{3}$} \\
\hline $\mathrm{CEBE}(\mathrm{Cls})\left[-\mathrm{CH}_{3}\right]$ & 290.7 & 304.62 & 1.0 & 14.4 & 0.54 \\
\hline $\mathrm{CEBE}(\mathrm{C} 1 \mathrm{~s})\left[-\mathrm{CH}_{3}\right]$ & 290.7 & 304.86 & 1.0 & 14.4 & 0.54 \\
\hline CEBE (C1s) $[-\underline{C H}]$ & 291.1 & 305.62 & 1.0 & 14.4 & 0.54 \\
\hline $\mathrm{CEBE}(\mathrm{Cls})\left[\mathrm{O}-\mathrm{CH}_{3}\right]$ & 292.4 & 306.59 & 1.0 & 14.4 & 0.54 \\
\hline $\mathrm{CEBE}(\mathrm{Cls})[-\mathrm{C}=\mathrm{O}]$ & 294.4 & 309.41 & 1.0 & 14.4 & 0.54 \\
\hline \multicolumn{6}{|l|}{ MMA } \\
\hline \multicolumn{6}{|l|}{$\mathrm{CH}_{2}=\mathrm{C}\left(\mathrm{CH}_{3}\right) \mathrm{COOCH}_{3}$} \\
\hline $\mathrm{CEBE}(\mathrm{Cls})\left[-\mathrm{CH}_{3}\right]$ & 290.6 & 304.70 & 1.0 & 14.4 & 0.54 \\
\hline $\mathrm{CEBE}(\mathrm{Cls})\left[\mathrm{HH}_{2}-\right]$ & 291.0 & 305.40 & 1.0 & 14.4 & 0.54 \\
\hline $\mathrm{CEBE}(\mathrm{C} 1 \mathrm{~s})\left[\mathrm{C}^{\prime}\right]$ & 291.0 & 305.75 & 1.0 & 14.4 & 0.54 \\
\hline $\mathrm{CEBE}(\mathrm{Cls})\left[\mathrm{O}-\mathrm{CH}_{3}\right]$ & 292.4 & 306.62 & 1.0 & 14.4 & 0.54 \\
\hline \multicolumn{6}{|l|}{ MA } \\
\hline \multicolumn{6}{|l|}{$\mathrm{CH}_{2}=\mathrm{CHCOOCH}_{3}$} \\
\hline CEBE (Cls) $\left[\mathrm{CH}_{2}^{-}\right]$ & 291.1 & 305.55 & 1.0 & 14.4 & 0.54 \\
\hline $\mathrm{CEBE}(\mathrm{C} 1 \mathrm{~s})\left[\underline{\mathrm{C}} \mathrm{H}^{-}\right]$ & 291.1 & 305.79 & 1.0 & 14.4 & 0.54 \\
\hline $\mathrm{CEBE}(\mathrm{Cls})\left[\mathrm{O}-\mathrm{CH}_{3}\right]$ & 292.5 & 306.63 & 1.0 & 14.4 & 0.54 \\
\hline $\mathrm{CEBE}(\mathrm{C} 1 \mathrm{~s})[\mathrm{O}-\mathrm{C}=\mathrm{O}]$ & 294.8 & 309.55 & 1.0 & 14.4 & 0.54 \\
\hline \multicolumn{6}{|l|}{ ACRA } \\
\hline \multicolumn{6}{|l|}{$\mathrm{CH}_{2}=\mathrm{CH}(\mathrm{COOH})$} \\
\hline CEBE (C1s) $\left[\mathrm{CH}_{2-}^{-}\right]$ & 291.3 & 305.74 & 1.0 & 14.4 & 0.54 \\
\hline $\mathrm{CEBE}(\mathrm{C} 1 \mathrm{~s})[\underline{\mathrm{C}} \mathrm{H}-]$ & 291.3 & 306.00 & 1.0 & 14.4 & 0.54 \\
\hline $\mathrm{CEBE}(\mathrm{Cls})[\mathrm{COOH}]$ & 295.2 & 309.86 & 1.0 & 14.4 & 0.54 \\
\hline
\end{tabular}

Cls relative intensity of each functional group for the model oligomers was considered as the number of the carbon for the functional group in the monomer unit of the fifteen polymers in Table II. In the table, we found an energy shifted value and a linewidth of each MO levels as 21.0 and $1.3 \mathrm{eV}$, respectively, by trial and error.

The theoretical analysis from the Koopmans' theorem showed fairly good accordance with experimental lineshape analysis as obtained by Beamson and Brrigs. ${ }^{34}$ We emphasize here that the theoretical results give an aid to perform experimental lineshape analysis. For example, in the case of polypropylene (Figure $2 b$ ), the single peak around $285.1 \mathrm{eV}$ results from theoretical values, $(305.4,305.5 \mathrm{eV}),(305.2,305.3 \mathrm{eV})$, and $(305.1$, $305.2 \mathrm{eV}$ ) of the $-\mathrm{CH},-\mathrm{CH}_{2}$, and $\mathrm{CH}_{3}$ components, respectively, for the model trimers. For polyvinyl methyl ketone (PVMK) (Figure 4b), the large peak around $285.3 \mathrm{eV}$ is due to calculated values, $306.0,305.8$, and $305.4 \mathrm{eV}$ of the $-\mathrm{CH}_{3},-\mathrm{CH}$, and $-\mathrm{CH}_{2}$ components, respectively, for the model dimers. As stated in previous paper, ${ }^{3}$ we assigned that the $\mathrm{C}_{1 \mathrm{~s}}$ broader peak of PMMA (Figure 5d) in the range of $284-288 \mathrm{eV}$ is composed of four components $\left(-\mathrm{CH}_{3},-\mathrm{CH}_{2}\right.$, $=\mathrm{C}_{-}^{-}$, and $\left.-\mathrm{OCH}_{3}\right)$.

\section{CEBEs and WD of Ten Polymers}

The computed CEBEs (Table III) of ten polymers (poly ethylene (PE), polypropylene (PP), poly(methylene glycol) (PMG), poly(vinyl alcohol) (PVA), poly(vinyl methyl ether) (PVME), poly(vinyl methyl ketone) (PVMK), poly(acrylic acid) (PAA), poly(methyl acrylate) (PMA), propylene glycol (PG), and poly(methyl methacrylate) (PMMA)) using uGTS model are much better agreement with observed values than were those pre- dicted by Koopmans' theorem, as shown in Table II. For the CEBEs with scaled-pVTZ basis set including the relativistic corrections, we obtained values of WD (the difference between the calculated and observed CEBEs) closer to the difference $(6.6 \mathrm{eV})$ between shifted values as used as 14.4 and $21.0 \mathrm{eV}$ for core C1s energy levels of the gas molecules and the model oligomers, respectively, in previous sections. The WDs also follow the trend of WD values assumed for the valence rigion of the XPS. We may therefore consider the another estimate of WD.

In Table III, we gave two different WDs as obtained from differences between the calculated and the observed CEBEs, and from valence region XPS based on $\mathrm{HAM} / 3$ calculations. When we take into consideration the long acquisition times of valence-region XPS due to the 20- to 100 -fold weaker intensities and hence the possible X-ray radiation damage, we conclude that the WD values from CEBEs may very well be the more reliable one among choice in Table III. For PMMA and MIB, the WD value, $5.2 \mathrm{eV}$, is in a good accordance with the experimental value, $5.4 \mathrm{eV}$, as obtained from the difference between experimental CEBEs ${ }^{15}$ of MIB molecule and PMMA (Figure 6). Consequently, the WD values may be underestimated by valence-region XPS based on HAM/3 calculations by 0.5 to $1.0 \mathrm{eV}$.

\section{CONCLUSION}

We have simulated $\mathrm{C}$ 1s spectra of $\mathrm{C}$ - and $\mathrm{O}$-containing polymers by ab initio MO calculations of HONDO7 program using the model oligomers. The theoretical spectra showed fairy good accordance with the experimental spectra, although the shifted value was used 
b)

a)

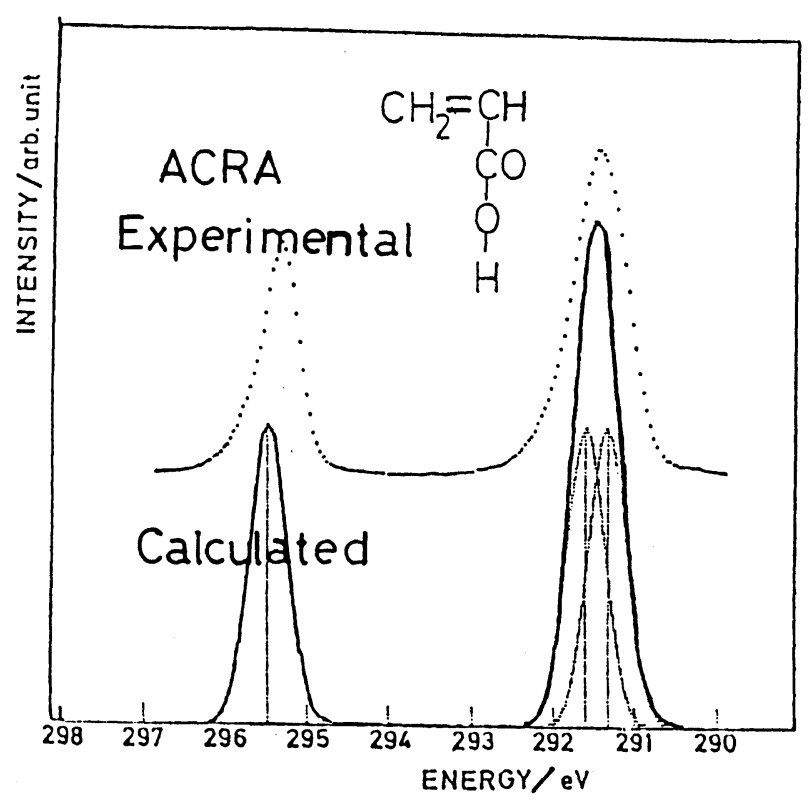

c)

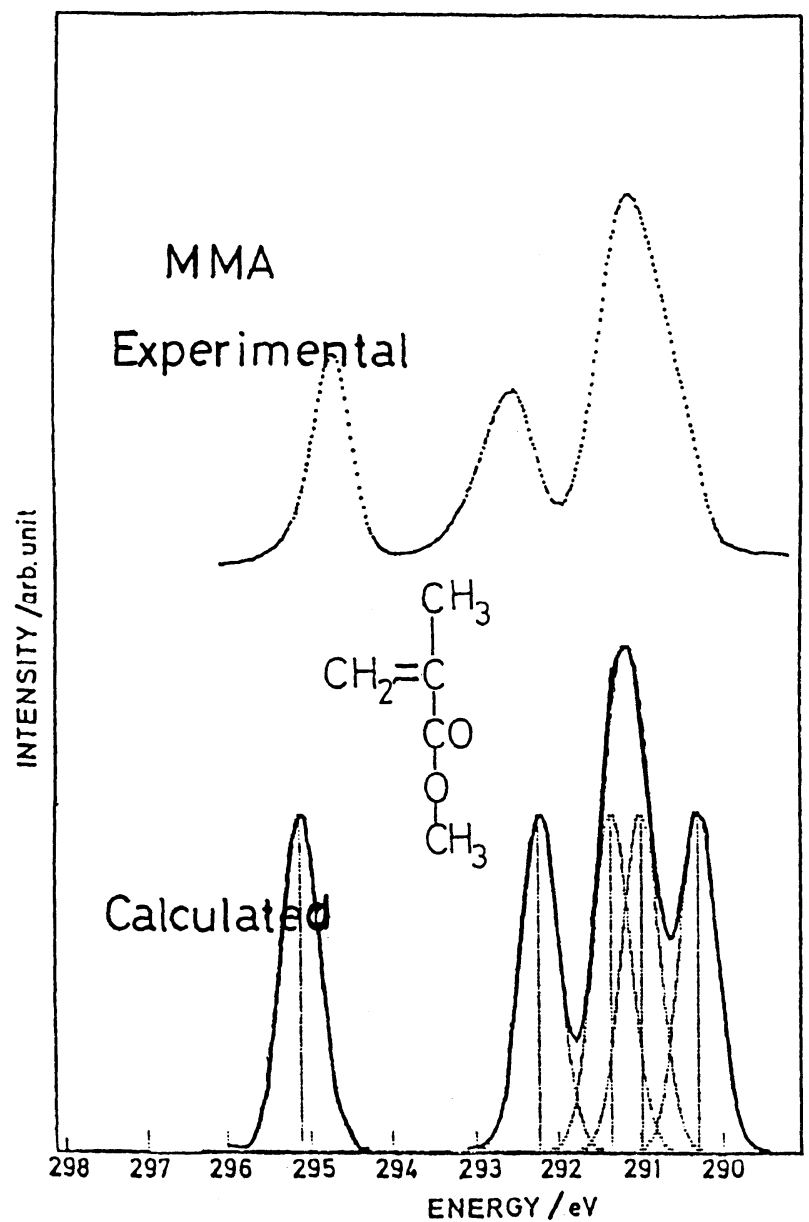

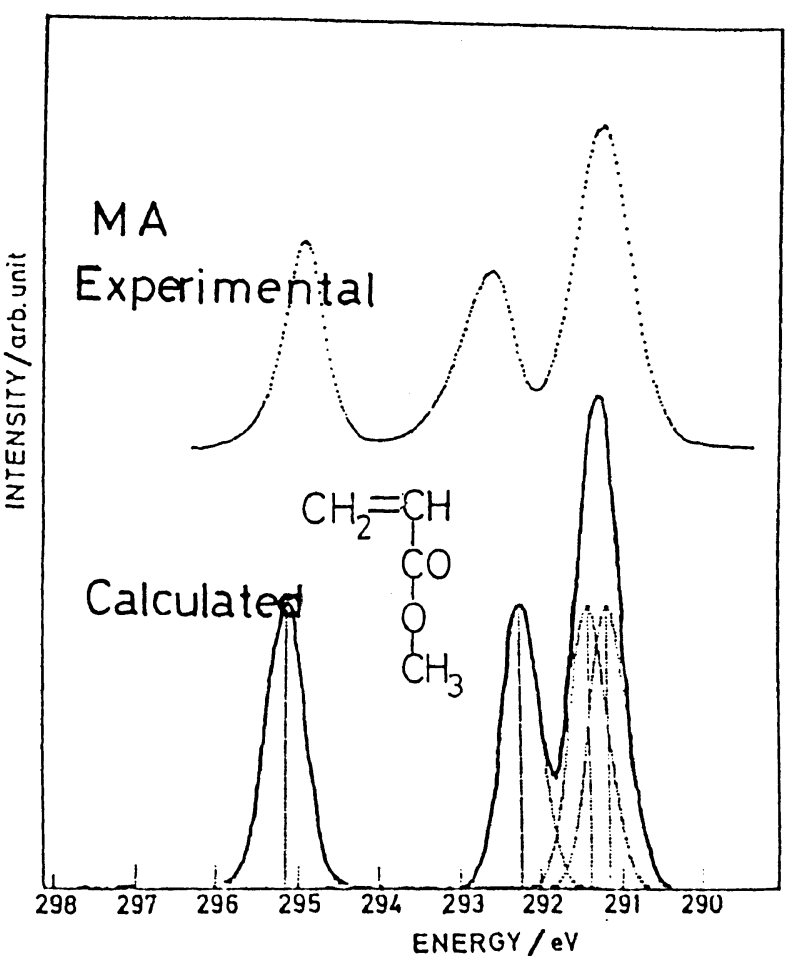

d)

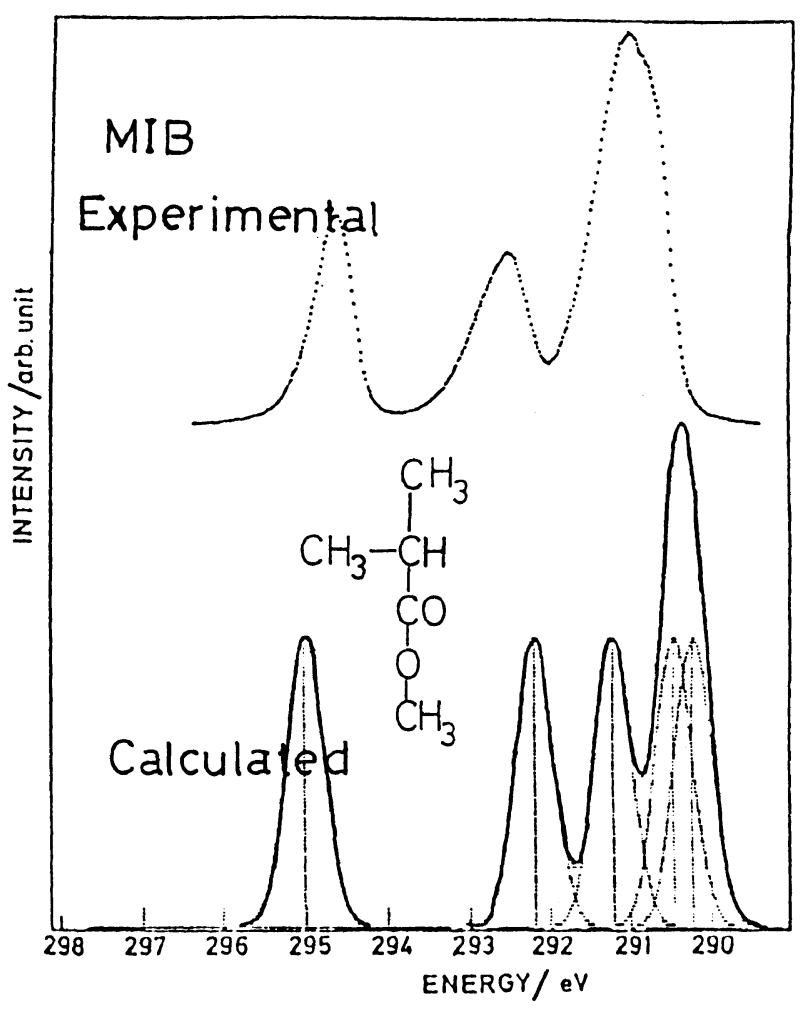

Figure 1. Core $\mathrm{C} 1 \mathrm{~s} \mathrm{X}$-ray photoelectron spectra of gas molecules with the simulated spectra of the molecules using HONDO7 program. a) acrylic acid (ACRA); b) methyl acrylate (MA); c) methyl methacrylate (MMA); d) methyl isobutyrate (MIB). 
a)

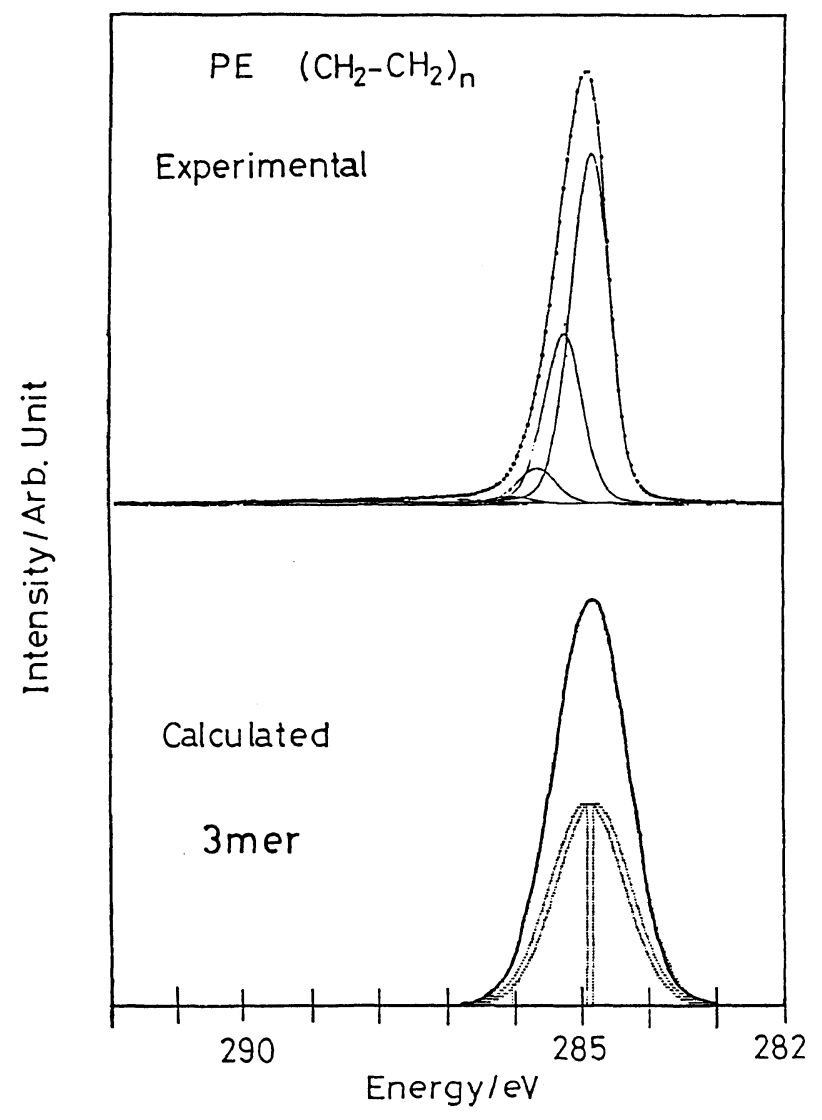

c)

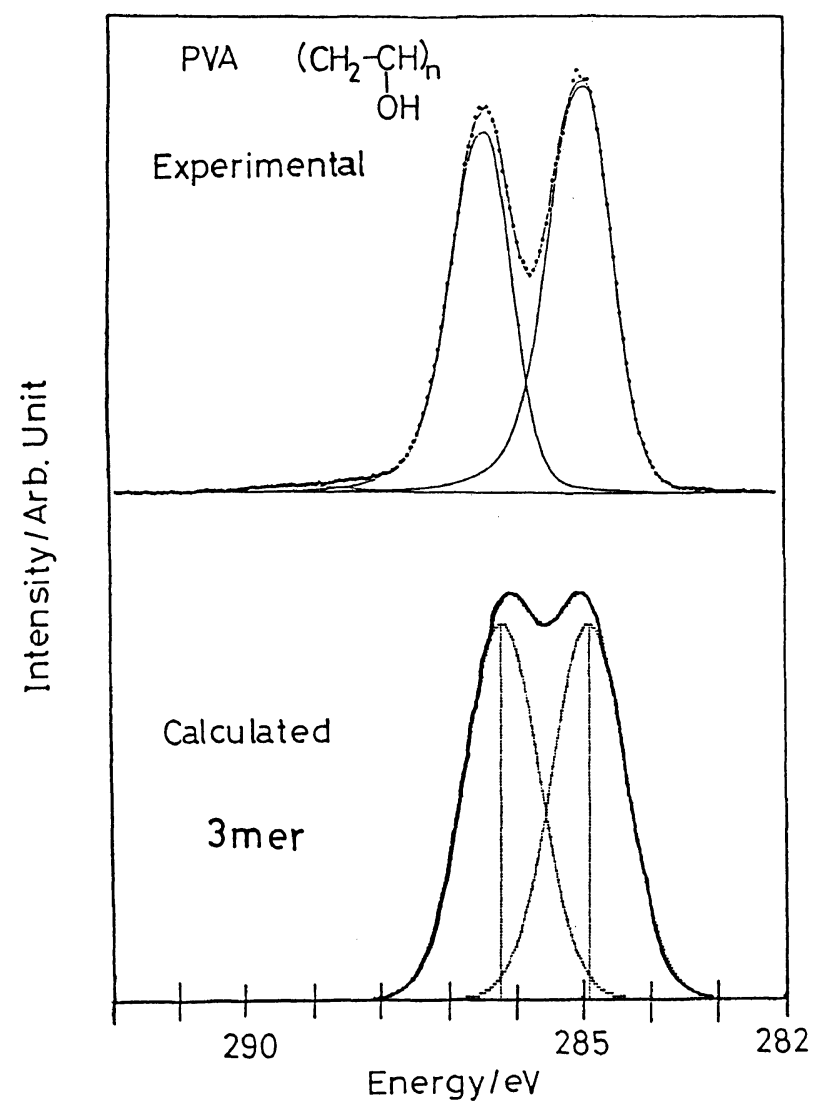

b)

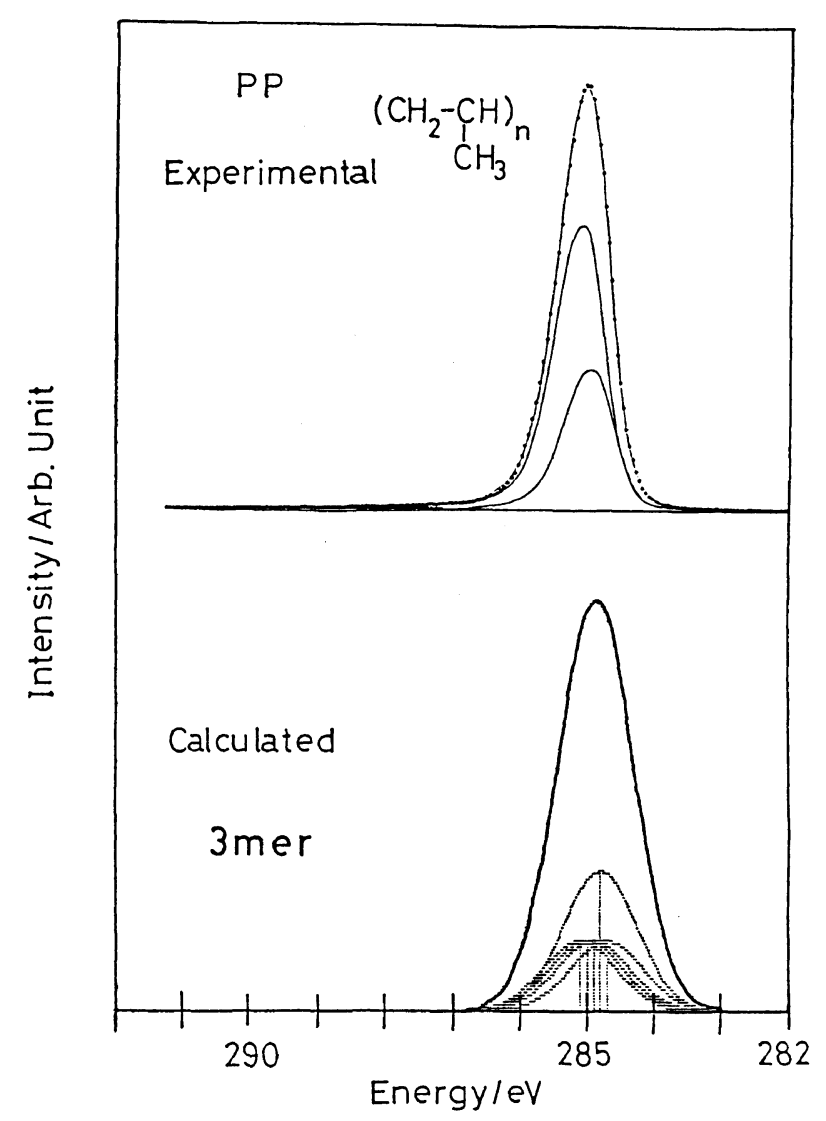

Figure 2. Core $\mathrm{Cls}$ X-ray photoelectron spectra of $\left(\mathrm{CH}_{2}-\mathrm{CHR}\right)_{n}$ $\left(\mathrm{R}=\mathrm{H}, \mathrm{CH}_{3}, \mathrm{OH}\right)$ with the simulated spectra of the model trimers using HONDO7 program. a) PE; b) PP; c) PVA. 
Table II. C1s binding energies (in eV) of C- and O-containing polymers by HONDO7 program using the model oligomers ${ }^{\mathbf{a}}$

\begin{tabular}{|c|c|c|c|c|c|}
\hline Polymer & Observed $^{b}$ & $\begin{array}{l}\text { Koopmans' } \\
\text { theorem }\end{array}$ & $\begin{array}{l}\text { Relative } \\
\text { intensity }\end{array}$ & $\begin{array}{l}\text { Shifted } \\
\text { value }\end{array}$ & $\begin{array}{l}\text { Linewidth } \\
\text { (halfwidth) }\end{array}$ \\
\hline $\begin{array}{l}\left(\mathrm{CH}_{2}-\mathrm{CH}_{2}\right)_{n} \\
\mathrm{CEBE}(\mathrm{Cls})\left[\mathrm{CH}_{2}^{-}\right]\end{array}$ & 285.0 & $\begin{array}{c}(3 \mathrm{mer}) \\
305.2 ; 305.2 ; 305.3,305.3\end{array}$ & 1.0 & 21.0 & 1.3 \\
\hline $\begin{array}{l}\left(\mathrm{CH}_{2}-\mathrm{CH}\left(\mathrm{CH}_{3}\right)\right)_{n} \\
\text { CEBE }(\mathrm{Cls})\left[-\mathrm{CH}_{3}\right] \\
\text { CEBE }(\mathrm{Cls})\left[\underline{\mathrm{CH}}{ }_{2}^{-}\right] \\
\text {CEBE }(\mathrm{Cls})[-\underline{-} \mathrm{CH}]\end{array}$ & $\begin{array}{l}285.0 \\
285.0 \\
285.2\end{array}$ & $\begin{array}{c}(3 \text { mer }) \\
305.1 ; 305.2 \\
305.2 ; 305.3 \\
305.4 ; 305.5\end{array}$ & $\begin{array}{l}1.0 \\
1.0 \\
1.0\end{array}$ & $\begin{array}{l}21.0 \\
21.0 \\
21.0\end{array}$ & $\begin{array}{l}1.3 \\
1.3 \\
1.3\end{array}$ \\
\hline $\begin{array}{l}\left(\mathrm{CH}_{2}-\mathrm{O}\right)_{n} \\
\quad \mathrm{CEBE}(\mathrm{Cls})\left[\mathrm{CH}_{2}-\right]\end{array}$ & 287.89 & $\begin{array}{c}(3 \text { mer }) \\
308.8 ; 308.9\end{array}$ & 1.0 & 21.0 & 1.3 \\
\hline $\begin{array}{l}\left(\mathrm{CH}_{2}-\mathrm{CH}_{2}-\mathrm{O}\right)_{n} \\
\quad \mathrm{CEBE}(\mathrm{Cls})\left[\mathrm{CH}_{2}-\right]\end{array}$ & 286.45 & $\begin{array}{c}(3 \text { mer }) \\
306.5 ; 306.6 ; 306.9 ; 307.2\end{array}$ & 1.0 & 21.0 & 1.3 \\
\hline $\begin{array}{l}\left(\mathrm{CH}_{2}-\mathrm{CH}_{2}-\mathrm{CH}_{2}-\mathrm{O}\right)_{n} \\
\mathrm{CEBE}(\mathrm{Cls})\left[\mathrm{C}-\mathrm{CH}_{2}-\mathrm{C}\right] \\
\text { CEBE }(\mathrm{Cls})\left[\mathrm{O}-\underline{\mathrm{CH}}_{2}-\mathrm{C}\right]\end{array}$ & $\begin{array}{l}285.00 \\
286.44\end{array}$ & $\begin{array}{c}(2 \mathrm{mer}) \\
305.2 \\
306.8 ; 306.9\end{array}$ & $\begin{array}{l}1.0 \\
1.0\end{array}$ & $\begin{array}{l}21.0 \\
21.0\end{array}$ & $\begin{array}{l}1.3 \\
1.3\end{array}$ \\
\hline $\begin{array}{r}\left(\mathrm{CH}_{2}-\mathrm{CH}_{2}-\mathrm{CH}_{2}-\mathrm{CH}_{2}-\mathrm{O}\right)_{n} \\
\mathrm{CEBE}(\mathrm{C} 1 \mathrm{~s})\left[\mathrm{C}-\mathrm{CH}_{2}-\mathrm{C}\right] \\
\mathrm{CEBE}(\mathrm{Cls})\left[\mathrm{O}-\mathrm{CH}_{2}-\mathrm{C}\right]\end{array}$ & $\begin{array}{l}285.00 \\
286.35\end{array}$ & $\begin{array}{c}(2 \mathrm{mer}) \\
305.1 ; 305.3 \\
306.7 ; 306.7\end{array}$ & $\begin{array}{l}1.0 \\
1.0\end{array}$ & $\begin{array}{l}21.0 \\
21.0\end{array}$ & $\begin{array}{l}1.3 \\
1.3\end{array}$ \\
\hline $\begin{array}{l}\left(\mathrm{CH}_{2}-\mathrm{CH}(\mathrm{OH})\right)_{n} \\
\mathrm{CEBE}(\mathrm{Cls})\left[\mathrm{CH}_{2}-\right] \\
\text { CEBE }(\mathrm{Cls})[\underline{\mathrm{C}} \mathrm{H}(\mathrm{OH})]\end{array}$ & $\begin{array}{l}285.0 \\
286.5\end{array}$ & $\begin{array}{c}(3 \text { mer }) \\
305.3 ; 305.3 \\
306.6 ; 306.6\end{array}$ & $\begin{array}{l}1.0 \\
1.0\end{array}$ & $\begin{array}{l}21.0 \\
21.0\end{array}$ & $\begin{array}{l}1.3 \\
1.3\end{array}$ \\
\hline $\begin{array}{l}\left(\mathrm{CH}_{2}-\mathrm{CH}\left(\mathrm{OCH}_{3}\right)\right)_{n} \\
\mathrm{CEBE}(\mathrm{C} 1 \mathrm{~s})\left[\mathrm{CH}_{2}-\right] \\
\mathrm{CEBE}(\mathrm{C} 1 \mathrm{~s})[\underline{\mathrm{C}}-] \\
\mathrm{CEBE}(\mathrm{C} 1 \mathrm{~s})\left[\mathrm{O}-\underline{\mathrm{CH}}_{3}\right]\end{array}$ & $\begin{array}{l}285.0 \\
286.5 \\
286.7\end{array}$ & $\begin{array}{l}(2 \mathrm{mer}) \\
305.1 \\
307.1 \\
306.7\end{array}$ & $\begin{array}{l}1.0 \\
1.0 \\
1.0\end{array}$ & $\begin{array}{l}21.0 \\
21.0 \\
21.0\end{array}$ & $\begin{array}{l}1.3 \\
1.3 \\
1.3\end{array}$ \\
\hline $\begin{array}{l}\left(\mathrm{CH}_{2}-\mathrm{CH}\left(\mathrm{COCH}_{3}\right)\right)_{n} \\
\mathrm{CEBE}(\mathrm{C} 1 \mathrm{~s})\left[\mathrm{CH}_{2}-\right] \\
\mathrm{CEBE}(\mathrm{C} 1 \mathrm{~s})\left[\mathrm{C} \mathrm{H}_{-}, \mathrm{CH}_{3}\right] \\
\mathrm{CEBE}(\mathrm{C} 1 \mathrm{~s})[-\mathrm{CO}]\end{array}$ & $\begin{array}{l}285.0 \\
285.4 \\
288.0\end{array}$ & $\begin{array}{c}(2 \mathrm{mer}) \\
305.4 \\
305.8 ; 306.0 \\
308.8\end{array}$ & $\begin{array}{l}1.0 \\
1.0 \\
1.0\end{array}$ & $\begin{array}{l}21.0 \\
21.0 \\
21.0\end{array}$ & $\begin{array}{l}1.3 \\
1.3 \\
1.3\end{array}$ \\
\hline $\begin{array}{l}\left(\mathrm{CH}_{2}-\mathrm{CH}(\mathrm{COOH})\right)_{n} \\
\mathrm{CEBE}(\mathrm{Cls})\left[\underline{\mathrm{CH}_{2}-}\right] \\
\mathrm{CEBE}(\mathrm{Cls})\left[\underline{\mathrm{C}} \mathrm{H}^{-}\right] \\
\mathrm{CEBE}(\mathrm{Cls})[\underline{\mathrm{COOH}}]\end{array}$ & $\begin{array}{l}285.0 \\
285.6 \\
289.1\end{array}$ & $\begin{array}{c}(3 \text { mer }) \\
305.9 ; 306.0 \\
306.4 ; 306.5 \\
310.4 ; 310.5\end{array}$ & $\begin{array}{l}1.0 \\
1.0 \\
1.0\end{array}$ & $\begin{array}{l}21.0 \\
21.0 \\
21.0\end{array}$ & $\begin{array}{l}1.3 \\
1.3 \\
1.3\end{array}$ \\
\hline $\begin{array}{c}\left.\left(\mathrm{CH}_{2}-\mathrm{CH}(\mathrm{OCOCH})_{3}\right)\right)_{n} \\
\mathrm{CEBE}(\mathrm{Cls})\left[\mathrm{CH}_{2}-\right] \\
\mathrm{CEBE}(\mathrm{Cls})[\underline{\mathrm{C}}-\mathrm{O}-] \\
\mathrm{CEBE}(\mathrm{Cls})\left[\mathrm{O}-\underline{\mathrm{C}} \mathrm{H}_{3}\right] \\
\mathrm{CEBE}(\mathrm{Cls})[\mathrm{O}-\underline{\mathrm{C}}=\mathrm{O}]\end{array}$ & $\begin{array}{l}285.0 \\
286.7 \\
285.7 \\
289.2\end{array}$ & $\begin{array}{c}(3 \text { mer }) \\
305.2 ; 305.3 \\
307.2 ; 307.2 \\
305.8 ; 305.9 \\
310.1 ; 310.2\end{array}$ & $\begin{array}{l}1.0 \\
1.0 \\
1.0 \\
1.0\end{array}$ & $\begin{array}{l}21.0 \\
21.0 \\
21.0 \\
21.0\end{array}$ & $\begin{array}{l}1.3 \\
1.3 \\
1.3 \\
1.3\end{array}$ \\
\hline $\begin{array}{c}\left(\mathrm{CH}_{2}-\mathrm{CHCOOCH}\right)_{n} \\
\mathrm{CEBE}(\mathrm{Cls})\left[\mathrm{CH}_{2}-\right] \\
\mathrm{CEBE}(\mathrm{Cls})[\underline{\mathrm{CH}}-] \\
\mathrm{CEBE}(\mathrm{Cls})\left[\mathrm{O}-\mathrm{CH}_{3}\right] \\
\text { CEBE }(\mathrm{Cls})[-\underline{\mathrm{C}}=\mathrm{O}]\end{array}$ & $\begin{array}{l}285.0 \\
285.4 \\
286.6 \\
289.0\end{array}$ & $\begin{array}{l}(2 \mathrm{mer}) \\
306.0 \\
306.0 \\
307.2 \\
309.1\end{array}$ & $\begin{array}{l}1.0 \\
1.0 \\
1.0 \\
1.0\end{array}$ & $\begin{array}{l}21.0 \\
21.0 \\
21.0 \\
21.0\end{array}$ & $\begin{array}{l}1.3 \\
1.3 \\
1.3 \\
1.3\end{array}$ \\
\hline $\begin{array}{l}\left(\mathrm{CH}_{2}-(\mathrm{CO})-\mathrm{O}\right)_{n} \\
\mathrm{CEBE}(\mathrm{Cls})\left[\mathrm{CH}_{2}-\right] \\
\text { CEBE }(\mathrm{Cls})[-\underline{\mathrm{C}}=\mathrm{O}]\end{array}$ & $\begin{array}{l}286.6 \\
289.0\end{array}$ & $\begin{array}{l}(2 \text { mer }) \\
308.3 \\
310.7\end{array}$ & $\begin{array}{l}1.0 \\
1.0\end{array}$ & $\begin{array}{l}21.0 \\
21.0\end{array}$ & $\begin{array}{l}1.3 \\
1.3\end{array}$ \\
\hline $\begin{array}{c}\left(\mathrm{CH}\left(\mathrm{CH}_{3}\right)-(\mathrm{CO})-\mathrm{O}\right)_{n} \\
\mathrm{CEBE}(\mathrm{Cls})\left[-\mathrm{CH}_{3}\right] \\
\mathrm{CEBE}(\mathrm{Cls})[\mathrm{CH}-] \\
\mathrm{CEBE}(\mathrm{Cls})[-\mathrm{C}=\mathrm{O}]\end{array}$ & $\begin{array}{l}285.0 \\
287.0 \\
289.1\end{array}$ & $\begin{array}{l}(2 \text { mer }) \\
305.9 \\
308.4 \\
310.5\end{array}$ & $\begin{array}{l}1.0 \\
1.0 \\
1.0\end{array}$ & $\begin{array}{l}21.0 \\
21.0 \\
21.0\end{array}$ & $\begin{array}{l}1.3 \\
1.3 \\
1.3\end{array}$ \\
\hline $\begin{array}{c}\left(\mathrm{CH}_{2}-\mathrm{C}\left(\mathrm{CH}_{3}\right) \mathrm{COOCH}_{3}\right)_{n} \\
\mathrm{CEBE}(\mathrm{Cls})\left[-\mathrm{CH}_{3}\right] \\
\mathrm{CEBE}(\mathrm{Cls})\left[\underline{\mathrm{CH}}{ }^{-}-\right] \\
\mathrm{CEBE}(\mathrm{Cls})\left[-\mathrm{C}^{-}\right] \\
\mathrm{CEBE}(\mathrm{Cls})\left[-\underline{\mathrm{CH}} \mathrm{H}_{3}\right] \\
\mathrm{CEBE}(\mathrm{Cls})[-\underline{\mathrm{C}}=\mathrm{O}]\end{array}$ & $\begin{array}{l}284.6 \\
285.2 \\
285.8 \\
286.8 \\
289.0\end{array}$ & $\begin{array}{l}(2 \text { mer }) \\
305.2 \\
306.0 \\
306.5 \\
306.9 \\
310.0\end{array}$ & $\begin{array}{l}1.0 \\
1.0 \\
1.0 \\
1.0 \\
1.0\end{array}$ & $\begin{array}{l}21.0 \\
21.0 \\
21.0 \\
21.0 \\
21.0\end{array}$ & $\begin{array}{l}1.3 \\
1.3 \\
1.3 \\
1.3 \\
1.3\end{array}$ \\
\hline
\end{tabular}

${ }^{a}$ We omitted the contribution of both edge segments of the main chain. ${ }^{\text {b}}$ Values were referred to G. Beamson, D. Briggs, "High Resolution XPS of Organic Polymers. The Scienta ESCA 3000 Database," Wiley, Chichester, 1992. 
a)

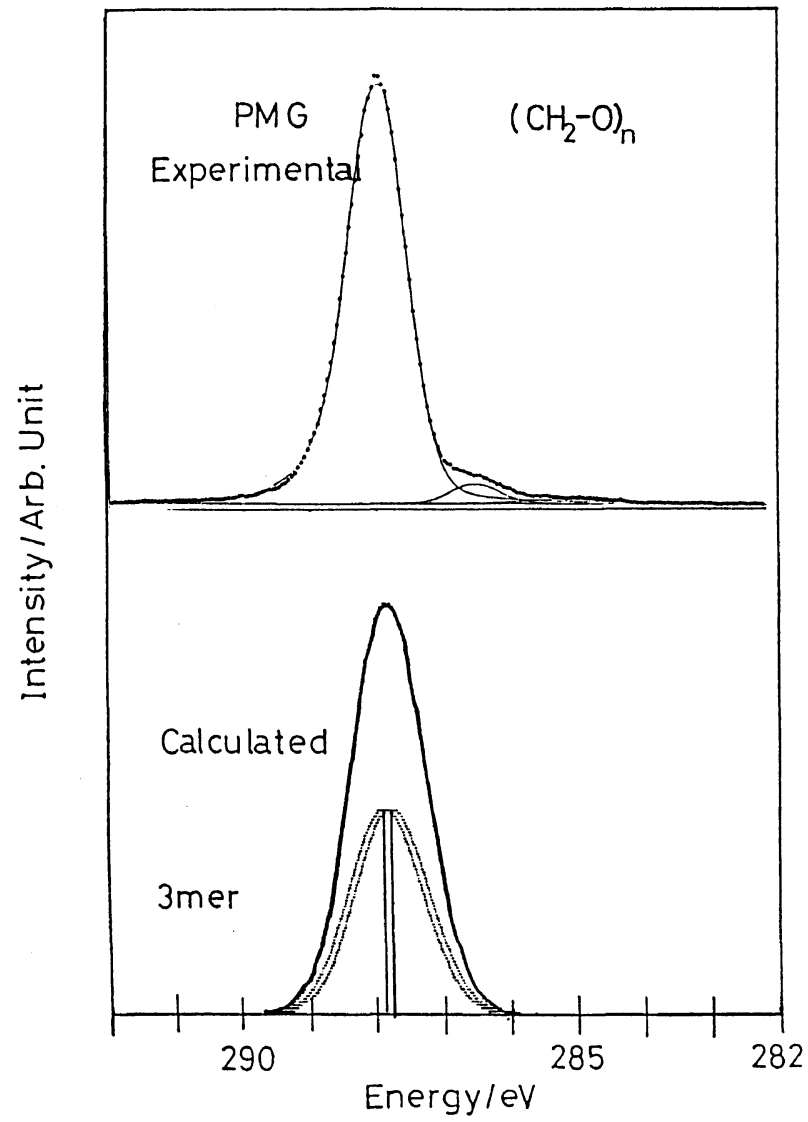

c)

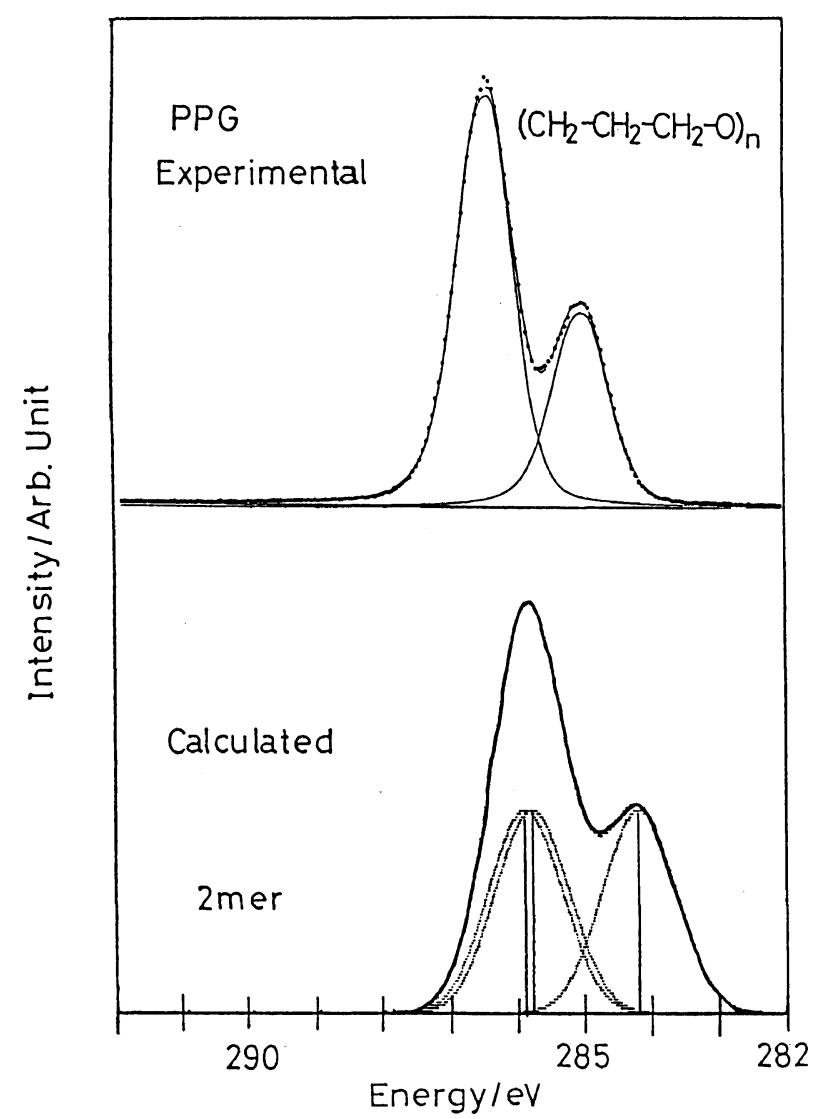

b)

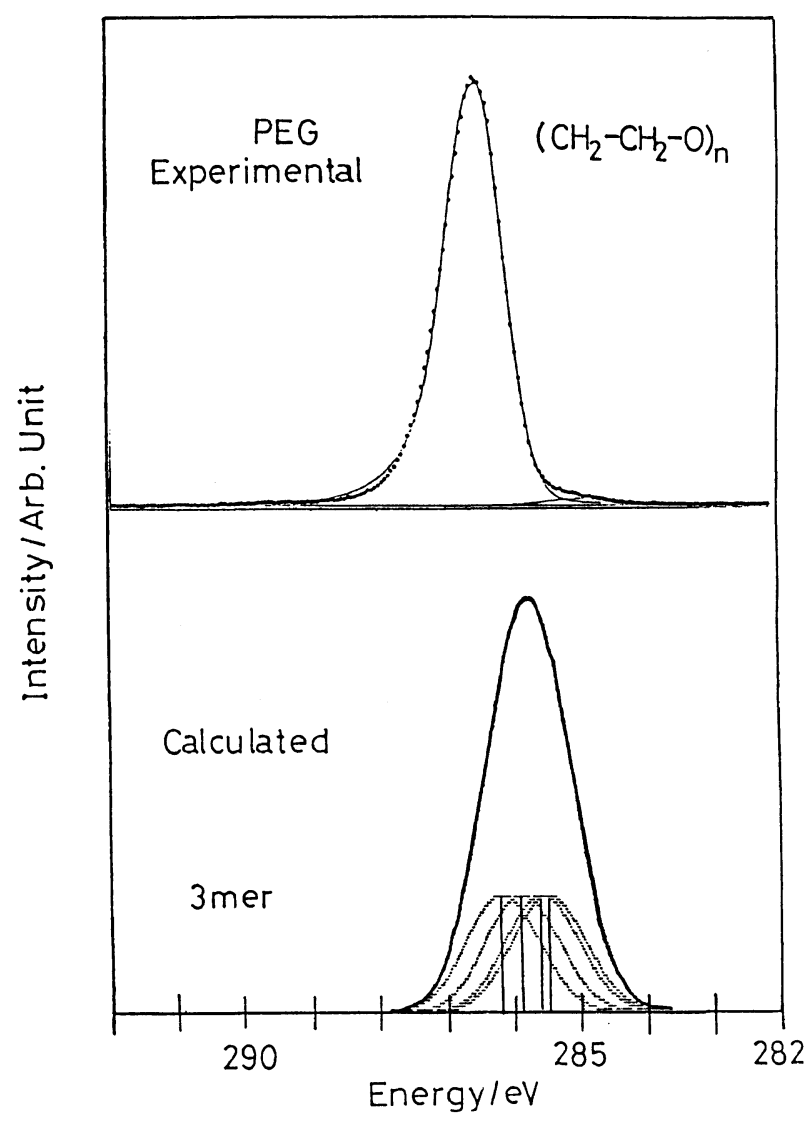

d)

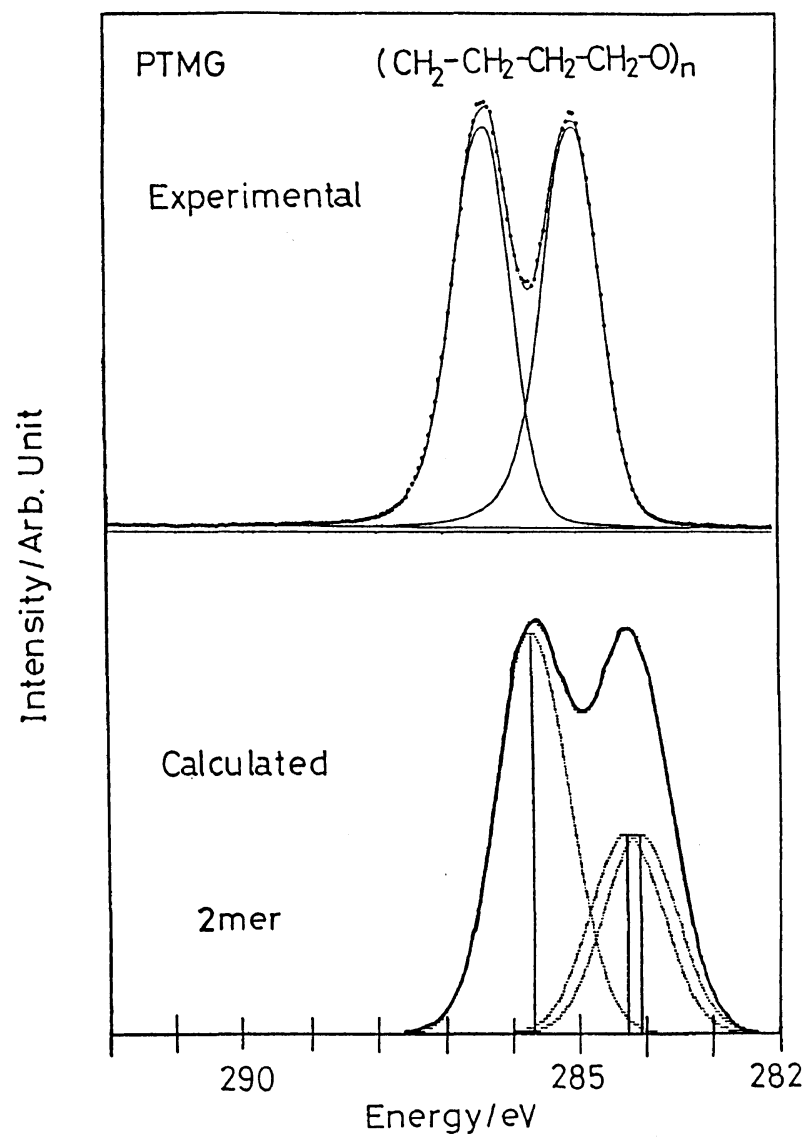

Figure 3. Core $\mathrm{C} 1 \mathrm{~s}$ X-ray photoelectron spectra of $\left(\mathrm{CH}_{k}-\mathrm{O}\right)_{n}(k=1-4)$ with the simulated spectra of the model trimers or dimers using $\mathrm{HONDO} 7$ program. a) PMG; b) PEG; c) PPG; d) PTMG. 
a)

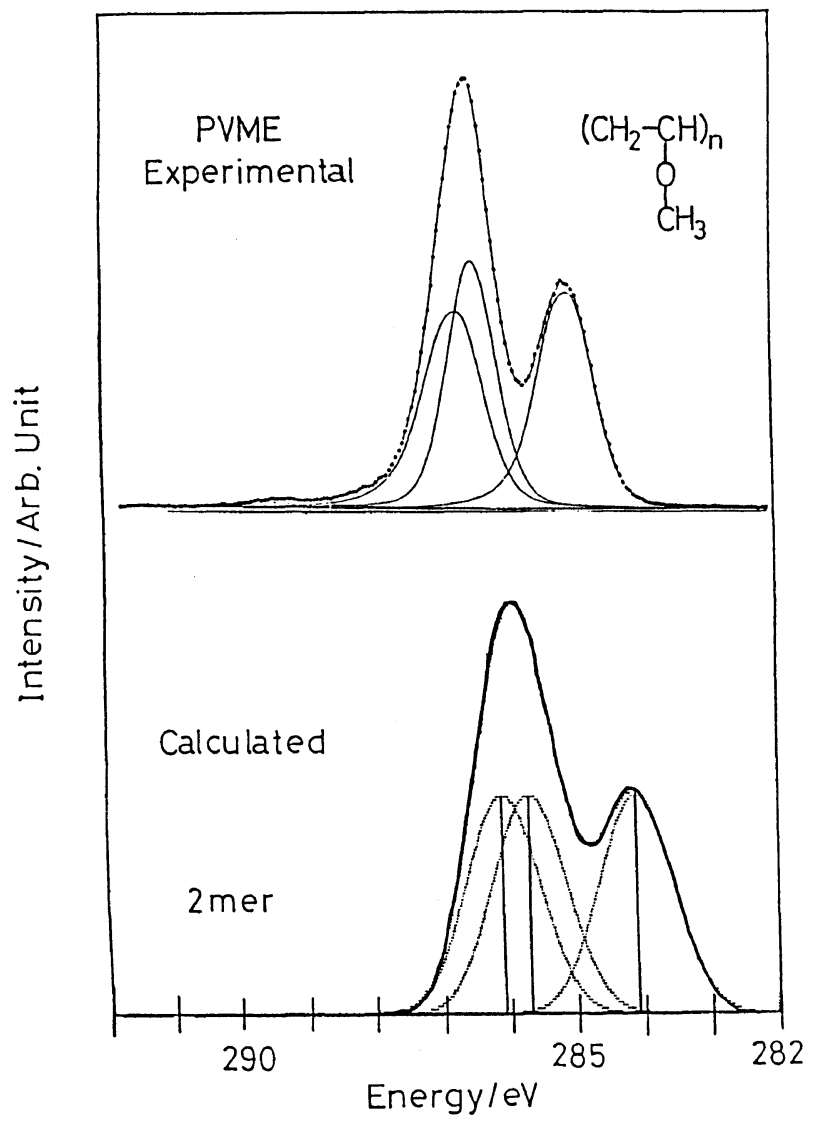

c)

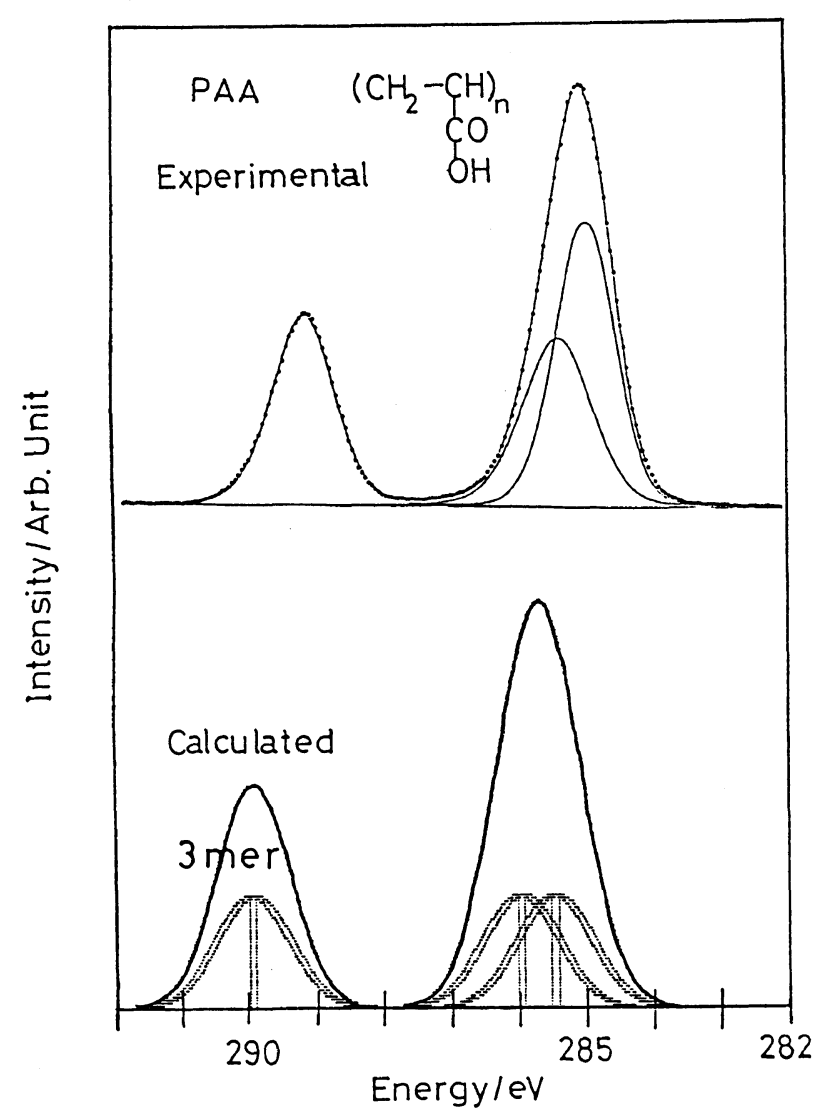

b)

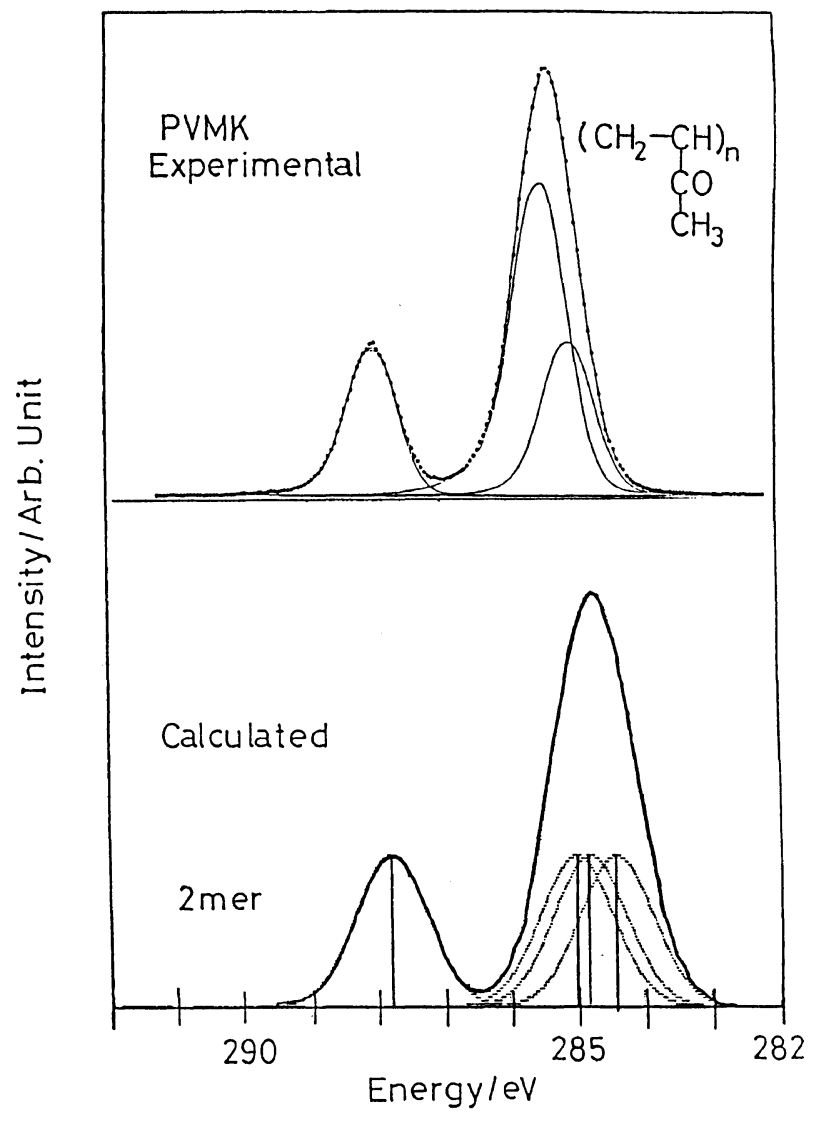

d)

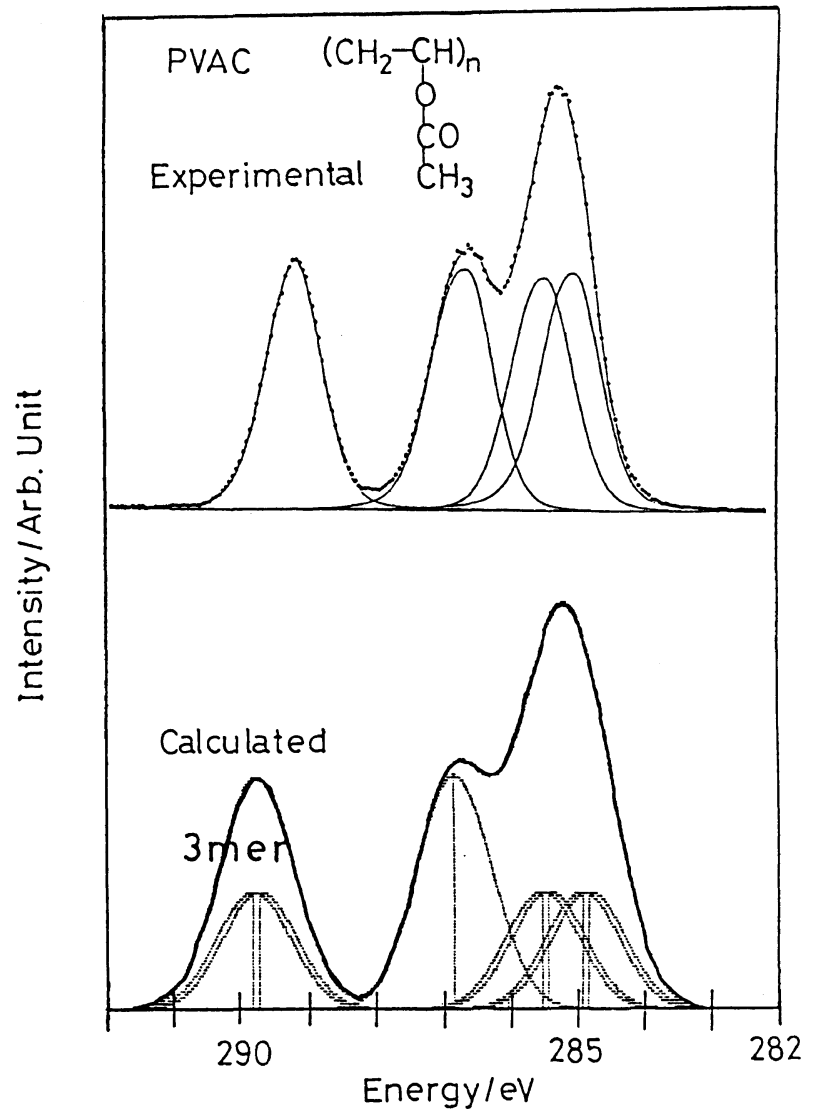

Figure 4. Core $\mathrm{Cls} \mathrm{X}$-ray photoelectron spectra of $\left(\mathrm{CH}_{2}-\mathrm{CHR}\right)_{n}\left(\mathrm{R}=\mathrm{OCH}_{3}, \mathrm{COCH}_{3}, \mathrm{COOH}, \mathrm{OCOCH}_{3}\right)$ with the simulated spectra of the model trimers or dimers using HONDO7 program. a) PVME; b) PVMK; c) PAA; d) poly(vinyl acetate) (PVAC). 
a)

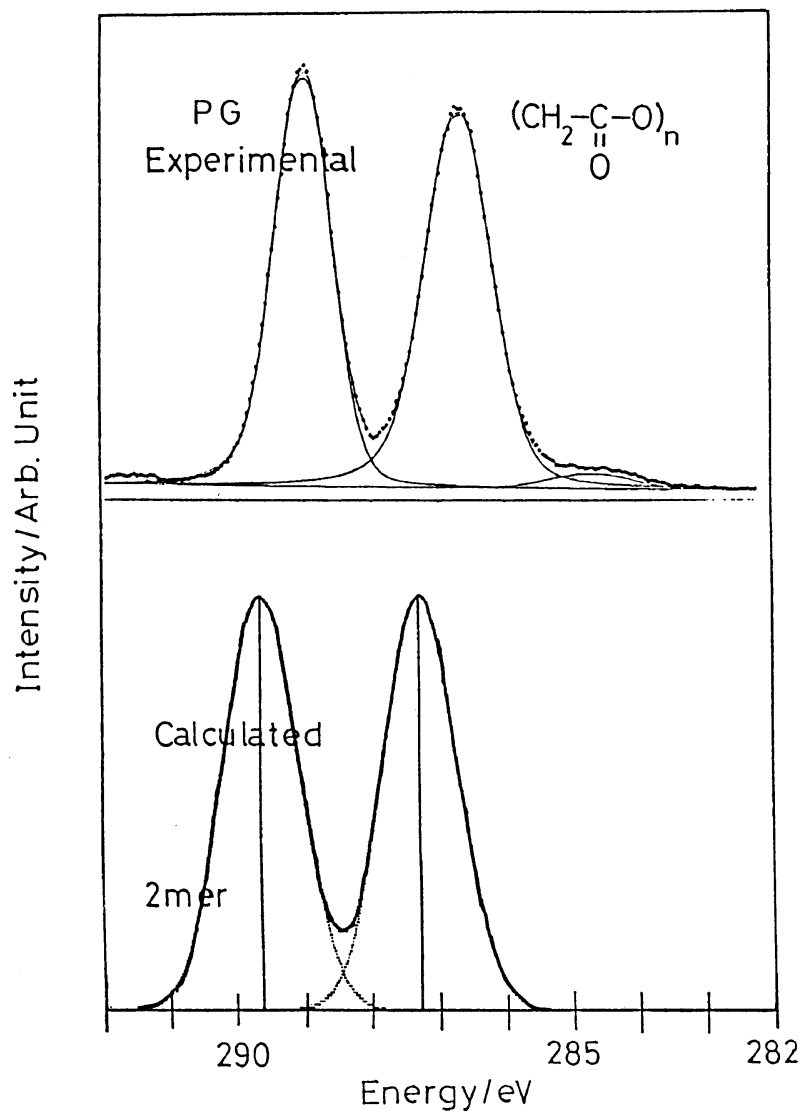

c)

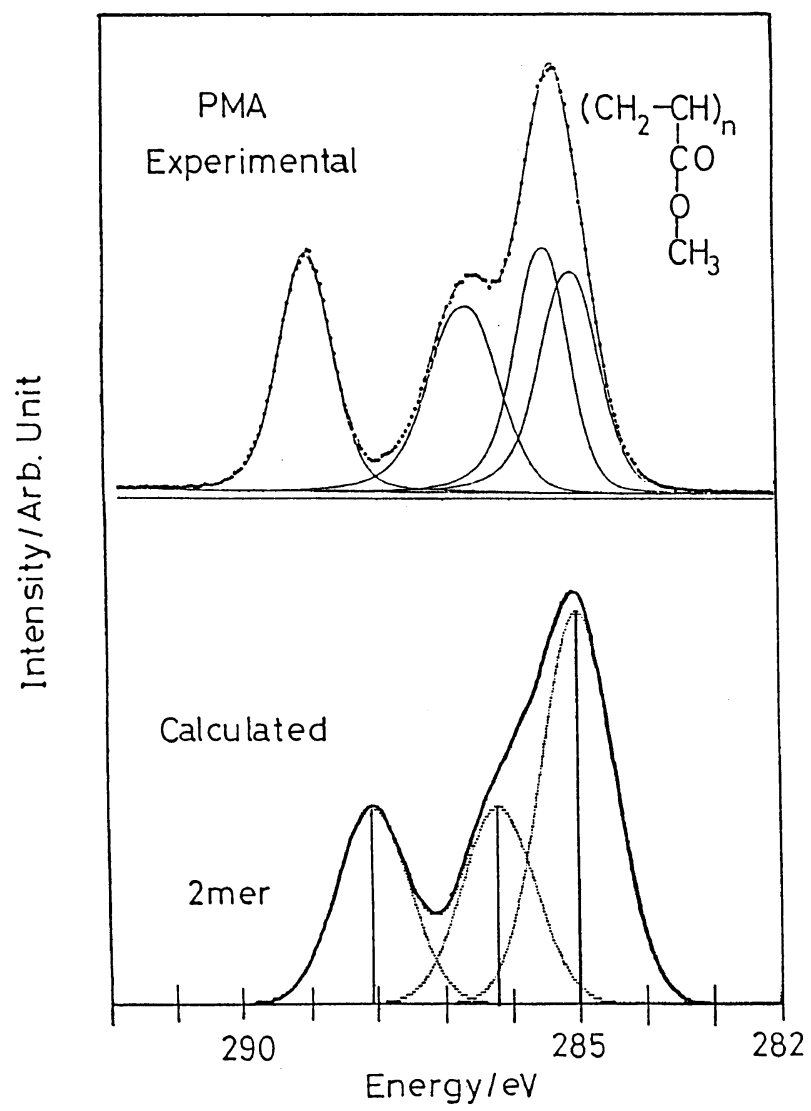

b)

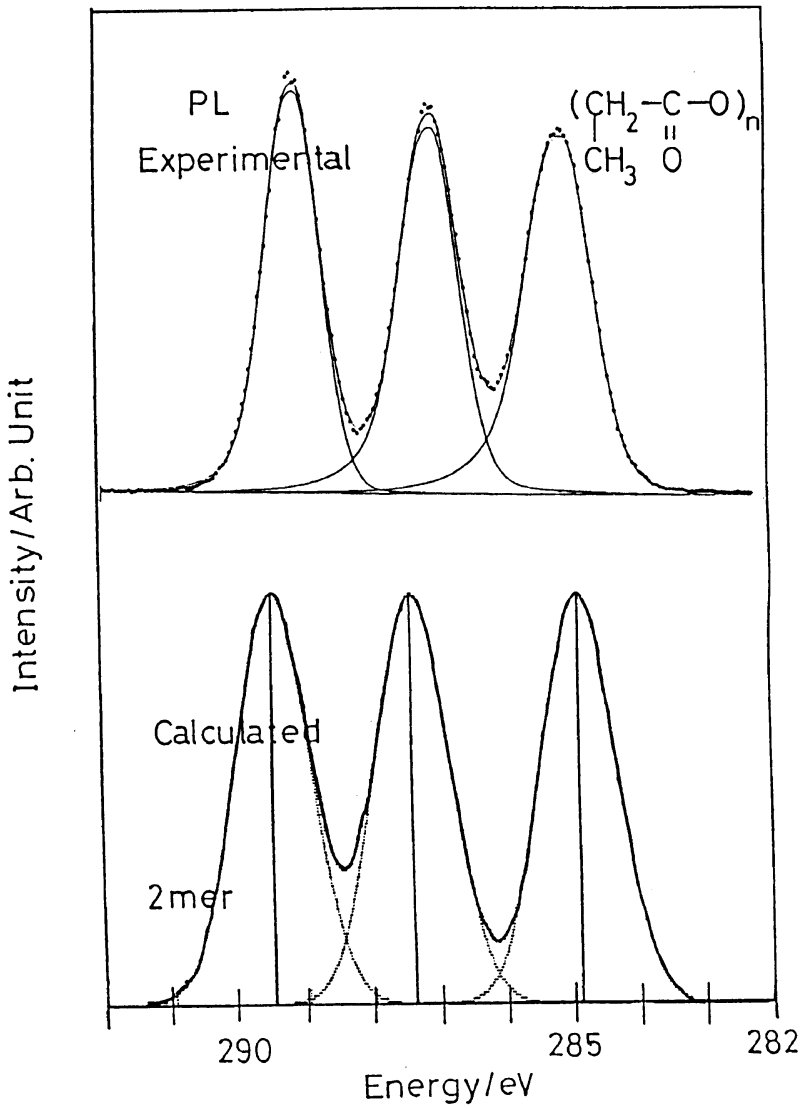

d)

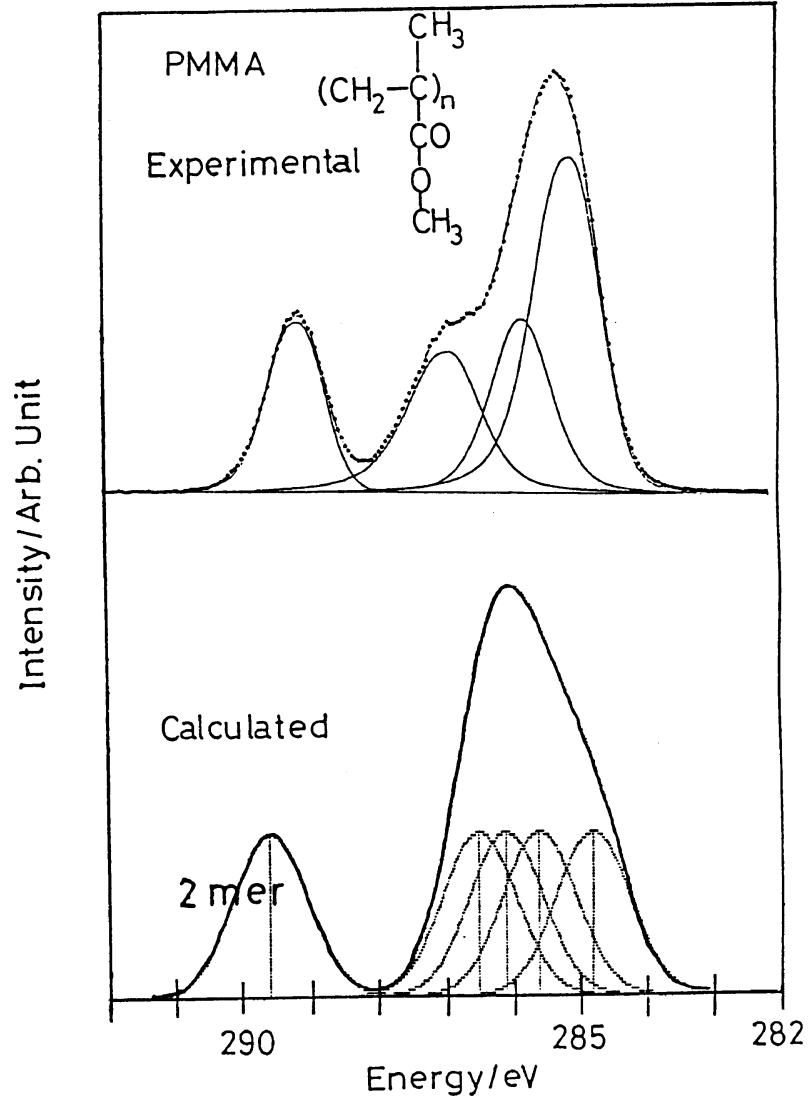

Figure 5. Core $\mathrm{Cls} \mathrm{X}$-ray photoelectron spectra of $(\mathrm{CHR}-\mathrm{CO}-\mathrm{O})_{n}\left(\mathrm{R}=\mathrm{H}, \mathrm{CH}_{3}\right),\left(\mathrm{CH}_{2}-\mathrm{CHCOOCH}_{3}\right)_{n}$ and $\left(\mathrm{CH}_{2}-\mathrm{C}\left(\mathrm{CH}_{3}\right) \mathrm{COOCH}_{3}\right)_{n}$ with the simulated spectra of the model dimers using HONDO7 program. a) PG; b) PL; c) PMA; d) PMMA. 
Table III. $\mathrm{Cls}$ binding energies and WDs of $\mathrm{C}$ - and O-containing polymers by deMon density-fuctional program using the model molecules ${ }^{\mathrm{a}}$ (in $\mathrm{eV}$ )

\begin{tabular}{|c|c|c|c|}
\hline Polymer & Observed $^{\mathrm{b}}$ & $\begin{array}{c}\text { Model } \\
\text { molecule } \\
\text { observed }\end{array}$ & $\begin{array}{c}\text { uGTS } \\
\text { scaled pVTZ } \\
\left(\Delta^{\mathrm{c}}\right)\end{array}$ \\
\hline $\begin{array}{l}\left(\mathrm{CH}_{2}-\mathrm{CH}_{2}\right)_{n} \\
\text { CEBE }(\mathrm{Cls})\left[\mathrm{CH}_{2}-\right]\end{array}$ & 285.0 & $2 \mathrm{mer}$ & $\begin{array}{r}291.05(6.1) \\
\langle 5.5\rangle^{+}\end{array}$ \\
\hline $\begin{array}{l}\left(\mathrm{CH}_{2}-\mathrm{CH}\left(\mathrm{CH}_{3}\right)\right)_{n} \\
\quad \mathrm{CEBE}(\mathrm{Cls})[-\underline{\mathrm{CH}}]\end{array}$ & 285.2 & $2 \mathrm{mer}$ & $\begin{aligned} & 290.67(5.5) \\
&\langle 5.5\rangle^{+}\end{aligned}$ \\
\hline $\begin{array}{l}\left(\mathrm{CH}_{2}-\mathrm{O}\right)_{n} \\
\quad \mathrm{CEBE}(\mathrm{Cls})\left[\mathrm{CH}_{2}-\right]\end{array}$ & 287.89 & $2 \mathrm{mer}$ & $\begin{array}{r}294.12(6.2) \\
\langle 5.0\rangle^{+}\end{array}$ \\
\hline $\begin{array}{l}\left(\mathrm{CH}_{2}-\mathrm{CH}(\mathrm{OH})\right)_{n} \\
\quad \mathrm{CEBE}(\mathrm{Cls})[\underline{\mathrm{CH}}(\mathrm{OH})]\end{array}$ & 286.5 & 1 mer-m & $\begin{array}{r}292.68(6.2) \\
\langle 4.5\rangle^{+}\end{array}$ \\
\hline $\begin{array}{l}\left(\mathrm{CH}_{2}-\mathrm{CH}\left(\mathrm{OCH}_{3}\right)\right)_{n} \\
\quad \mathrm{CEBE}(\mathrm{Cls})[\underline{\mathrm{CH}}-]\end{array}$ & 286.5 & 1 mer-m & $\begin{array}{r}292.19(5.7) \\
\langle 4.5\rangle^{+}\end{array}$ \\
\hline $\begin{array}{l}\left(\mathrm{CH}_{2}-\mathrm{CH}\left(\mathrm{COCH}_{3}\right)\right)_{n} \\
\quad \mathrm{CEBE}(\mathrm{Cls})[-\mathrm{CO}]\end{array}$ & 288.0 & 2 mer & $\begin{aligned} 292.87 & (4.9) \\
& \langle 4.5\rangle^{+}\end{aligned}$ \\
\hline $\begin{array}{l}\left(\mathrm{CH}_{2}-\mathrm{CH}(\mathrm{COOH})\right)_{n} \\
\quad \mathrm{CEBE}(\mathrm{C} 1 \mathrm{~s})[\mathrm{COOH}]\end{array}$ & 289.1 & $1 \mathrm{mer}$ & $\begin{array}{r}294.66(5.6) \\
\langle 3.5\rangle^{+}\end{array}$ \\
\hline $\begin{array}{l}\left(\mathrm{CH}_{2}-\mathrm{CHCOOCH}\right)_{n} \\
\quad \mathrm{CEBE}(\mathrm{C} 1 \mathrm{~s})[-\underline{\mathrm{C}}=\mathrm{O}]\end{array}$ & 289.0 & $1 \mathrm{mer}$ & $\begin{array}{r}294.40(5.4) \\
\langle 3.5\rangle^{+}\end{array}$ \\
\hline $\begin{array}{l}\left(\mathrm{CH}_{2}-(\mathrm{CO})-\mathrm{O}\right)_{n} \\
\quad \mathrm{CEBE}(\mathrm{C} 1 \mathrm{~s})[-\underline{\mathrm{C}}=\mathrm{O}]\end{array}$ & 289.0 & $1 \mathrm{mer}-\mathrm{m}$ & $\begin{array}{r}294.66(5.7) \\
\langle 5.0\rangle^{+}\end{array}$ \\
\hline $\begin{array}{c}\left(\mathrm{CH}_{2}-\mathrm{C}\left(\mathrm{CH}_{3}\right) \mathrm{COOCH}_{3}\right)_{n} \\
\mathrm{CEBE}(\mathrm{Cls})[-\mathrm{C}=\mathrm{O}]\end{array}$ & $\begin{array}{r}289.0 \\
\mathrm{CH}_{3} \\
\mathrm{CEBE}(\mathrm{Cl}\end{array}$ & $\begin{array}{c}1 \mathrm{mer} \\
\\
{\left[-\mathrm{C}\left(\mathrm{CH}_{3}\right) \mathrm{O}\right.} \\
{[-\mathrm{O}]}\end{array}$ & $\begin{array}{l}294.15(5.2) \\
\langle 3.5\rangle^{+} \\
\mathrm{OOCH}_{3} \\
294.43^{*}[5.4]^{*}\end{array}$ \\
\hline
\end{tabular}

${ }^{a}$ We omitted the contribution of both edge segments of the main chain. " Values were referred to G. Beamson and D. Briggs, "High Resolution XPS of Organic Polymers. The Scienta ESCA 3000 Database," Wiley, Chichester (1992). " Values denote the differences between the calculated CEBEs using uGTS model and the observed ones. + Values were obtained from analysis of valence XPS using $\mathrm{HAM} / 3$. ${ }^{*}$ Values were obtained from experimental results. ${ }^{15,35}$

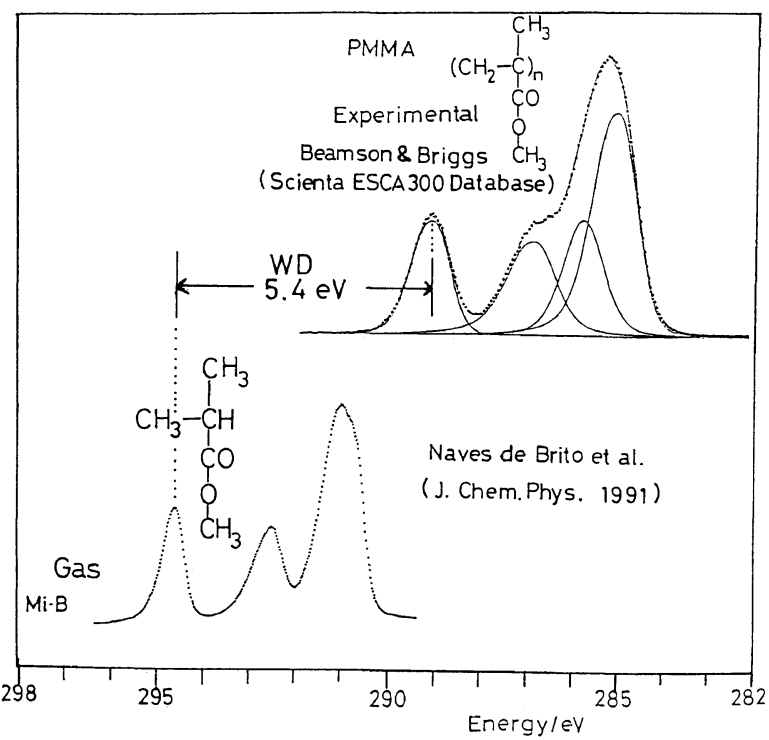

Figure 6. Experimental WD of PMMA as obtained from the difference between $\mathrm{C} 1 \mathrm{~s}$ of $-\mathrm{CO}-$ group of MIB and PMMA. ${ }^{13,35}$
$21.0 \mathrm{eV}$ for $\mathrm{C} 1 \mathrm{~s}$ energy levels of the oligomers. We emphasize that the theoretical results provide an aid to perform experimental lineshape analysis, by considering the examples of the PP, PVMK, and PMMA.

The calculated CEBEs of polymer models using uGTS model by deMon DFT program showed better correspondence with experiment than were those predicted by Koopmans' theorem. The WD values from the calculated and observed CEBEs of polymers may very well be the more reliable than ones we obtained for VIPs in the valence region.

Acknowledgments. We are grateful to Professor D. P. Chong of University of British Coloumbia for their valuable suggestion for the $a b$ initio DFT calculations using deMon program. We thank Dr. D. R. Salahub of University of Montreal for an early version of the deMon density functional program.

\section{REFERENCES}

1. K. Endo, N. Kobayashi, M. Aida, and C. Inoue, J. Phys. Chem. Solids, 54, 887 (1993).

2. K. Endo, C. Inoue, N. Kobayashi, T. Higashioji, and H. Nakatsuji, Bull. Chem. Soc. Jpn., 66, 3241 (1993).

3. K. Endo, C. Inoue, N. Kobayashi, and M. Aida, J. Phys. Chem. Solids, 55, 471 (1994).

4. C. Inoue, Y. Kaneda, M. Aida, and K. Endo, Polym. J., 27, 300 (1995).

5. K. Endo, Y. Kaneda, M. Aida, and D. P. Chong, J. Phys. Chem. Solids, in press.

6. M. Aida, Y. Kaneda, N. Kobayashi, K. Endo, and D. P. Chong, Bull. Chem. Soc. Jpn., 67, 2972 (1994).

7. K. Endo, C. Inoue, Y. Kaneda, M. Aida, N. Kobayashi, and D. P. Chong, Bull. Chem. Soc. Jpn., 68, 528 (1995).

8. K. Endo, J. Korean Vac. Soc., 5 (S1), 107 (1966).

9. K. Endo, Y. Kaneda, H. Okada, D. P. Chong, and P. Duffy, J. Phys. Chem. in press.

10. K. Endo, M. Aida, H. Okada, D. P. Chong, and P. Duffy, to be published.

11. J. C. Slater, Advan. Quantum Chem., 6, 1 (1972).

12. P. Boulanger, C. Magermans, J. J. Verbist, J. Delhalle, and D. S. Urch, Macromolecules, 24, 2757 (1991).

13. E. Orti and J. L. Bredas, J. Chem. Phys., 89, 1009 (1988).

14. J. L. Bredas and T. C. Clarke, J. Chem. Phys., 86, 253 (1987); Chem. Phys. Lett., 164, 240 (1989).

15. A. Naves de Brito, N. Correia, S. Svensson, and H. Agren, J. Chem. Phys., 95, 2965 (1991).

16. A. Naves de Brito, M. P. Keane, N. Correia, U. Gelius, and B. Lindberg, J. Surf. Interface Anal., 17, 94 (1991).

17. L. Asbrink, C. Fridh, and E. Lindholm, Chem. Phys. Lett., 52, 63 (1997): Quantum Chemistry Program Exchange, 12, No. 398 (1980).

18. L. Asbrink, C. Fridh, and E. Lindholm, Chem. Phys. Lett., 52, 69 (1977).

19. E. Lindholm and L. Asbrink, "Molecular Orbitals and their Energies, Studied by the Semiempirical HAM Method," Springer-Verlag, Berlin, 1985.

20. D. P. Chong, Can. J. Chem., 63, 2007 (1985).

21. A. St-Amant and D. R. Salahub, Chem. Phys. Lett., 169, 387 (1990); A. St-Amant, Ph. D. Thesis, University of Montreal (1991).

22. D. P. Chong, Chem. Phys. Lett., 220, 102 (1994).

23. P. Duffy and D. P. Chong, Org. Mass Spectrom., 28, 321 (1993).

24. D. P. Chong, Chem. Phys. Lett., 232, 486 (1995).

25. D. P. Chong, J. Chem. Phys., 103, 1842 (1995).

26. D. P. Chong, C.-H. Hu, and P. Duffy, Chem. Phys. Lett., 249, 491 (1996).

27. M. S. Dupuis, J. D. Watts, H. G. Villar, and G. J. B. Hurst, HONDO, version 7; Scientific and Engineering Computations Dept. 48B, IBM Corp; New York, 12401; 1978. 
28. S. Huzinaga, J. Andzelm, M. Klobukoski, E. Radzio-Andzelm, Y. Sakai, and H. Takewaki, "Gaussian Basis Sets for Molecular Calculations," Elsevier, Amsterdam, 1984.

29. T. H. Dunning, Jr. and P. J. Hay, in "Methods of Electronic Structure Theory," H. F. Schaefer, III, Ed., Plenum, New York, 1977.

30. M. J. S. Dewar and E. G. Zoebisch, Theochem., 180, 1 (1988); M. J. S. Dewar, E. G. Zoebisch, E. F. Healy, and J. J. P. Stewart,
J. Am. Chem. Soc., 107, 3902 (1985).

31. A. R. Williams, R. A. deGroot, and C. B. Sommers, J. Chem. Phys., 63, 628 (1975).

32. A. D. Becke, Phys. Rev., A38, 3098 (1988).

33. J. P. Perdew, Phys. Rev., B33, 8822 (1986).

34. G. Beamson and D. Briggs, "High Resolution XPS of Organic Polymers. The Scienta ESCA 3000 Database.” Wiley, Chichester, 1992. 